\title{
VIOLÊNCIAS E RESISTÊNCIAS: POVOS INDÍGENAS DO BRASIL E O POVO PURUBORÁ DA ALDEIA APEROI - RO ${ }^{1}$
}

\author{
ANATÁLIA DAIANE DE OLIVEIRA RAMOS ${ }^{2}$ \\ UFMT, BRASIL \\ http://orcid.org/0000-0001-9792-7520 \\ MARLI LÚCIA TONATTO ZIBETTI ${ }^{3}$ \\ UNIR, BRASIL \\ http://orcid.org/0000-0003-3939-5663 \\ EDSON CAETANO \\ UFMT, BRASIL \\ http://orcid.org/0000-0001-9906-0692
}

\begin{abstract}
RESUMO: Desde a invasão do Brasil, a história dos povos indigenas foi marcada pela violência e violação de seus direitos, bem como pela resistência dos mesmos. Este artigo objetiva analisar as denúncias de violências e violações de direitos, especialmente aquelas apontadas nos relatórios de violência contra os povos indígenas, elaborados pelo Conselho Indigenista Missionário (2014 a 2019), como também visibilizar as resistências dos indígenas. Para dialogar com esses dados, apresentam-se informações de duas pesquisas (mestrado e doutorado), desenvolvidas nos anos de 2014 a 2019 junto ao povo Puruborá da aldeia Aperoi, Seringueiras/RO. Os instrumentos utilizados para a produção de dados foram a observação participante - registrada em diário de campo, fotografias e vídeos -, análise documental e entrevista semiestruturada. A análise ocorreu por meio da triangulação das informações, da finalidade do texto e o referencial teórico empregado. A análise aponta as violações de direitos e as violências contra a pessoa, os povos indígenas isolados e de pouco contato, o patrimônio desses povos e a omissão do poder público. A sobrevivência desses povos decorre de sua organização e resistência histórica.
\end{abstract}

PALAVRAS-CHAVE: violências, resistências, povos indígenas, povo Puruborá, aldeia Aperoi.

ABSTRACT: Since the invasion of Brazil, the history of indigenous peoples has been marked by violence and violation of their rights, as well as their resistance. This article aims to analyze the denunciations of violence and rights violations, especially those pointed out in the reports of violence against indigenous peoples, prepared by the Indigenous Missionary Council (2014 to 2019), as well as to show the resistances of the indigenous people. In order to dialogue with these data, information from two surveys (master's and doctorate), developed in the years 2014 to 2019 with the Puruborá people of the Aperoi village, Seringueiras $/ R O$, is presented. The instruments used for the production of data were participant observation - recorded in a field diary,

${ }^{1}$ O presente texto foi realizado com apoio da Coordenação de Aperfeiçoamento de Pessoal de Nível Superior - Brasil (CAPES).

2 Doutora em Educação pela Universidade Federal de Mato Grosso (UFMT). E-mail: anataliadaiane@hotmail.com

3 Docente do Departamento de Psicologia da Universidade Federal de Rondônia (UNIR). E-mail: marlizibetti@yahoo.com.br

${ }^{4}$ Professor do Instituto de Educação (IE) da Universidade Federal de Mato Grosso (UFMT). E-mail: caetanoedson@hotmail.com

RAMOS, Anatália Daiane de Oliveira; ZIBETTI, Marli Lúcia Tonatto; CAETANO, Edson . Violências e resistências: povos indígenas do brasil e o povo Puruborá da aldeia Aperoi - RO. Espaço Ameríndio, Porto Alegre, v. 15, n. 2, p. 206-238, mai./ago. 2021. 
Espaço Ameríndio

photographs and videos -, document analysis and semi-structured interview. The analysis occurred through the triangulation of information, the purpose of the text and the theoretical framework employed. The analysis points out the violations of rights and the violence against the person, the isolated indigenous peoples and of little contact, the patrimony of these peoples and the omission of the public power. The survival of these peoples results from their organization and historical resistance.

KEYWORDS: violence, resistances, indigenous peoples, Puruborá people, Aperoi village. 


\section{Introdução}

Desde a invasão do Brasil, a existência dos povos indígenas do país foi e ainda é alicerçada na violência e na violação de seus direitos, na luta e na resistência destes povos frente à lógica capitalista de viver e produzir.

Os povos indígenas persistem em defender e experienciar sua lógica de viver que, ao priorizar o ser humano, a natureza e os demais seres vivos em detrimento do lucro, ocasiona conflitos de diversas ordens com o modo de produção capitalista. Por isso, precisam resistir para manter suas existências tradicionais, ancestrais e autóctones, bem como para garantir que os direitos arduamente conquistados, por exemplo, na Declaração Universal dos Direitos Humanos (1948) e na Constituição Federal do Brasil (1988), sejam efetivamente materializados.

Entretanto, essa resistência, ou melhor, resistências, denunciam os problemas enfrentados pelos povos indígenas no Brasil, entre eles, as violências e violações dos seus direitos. Essas violências e violações dos direitos indígenas de nosso país têm sido sistematicamente denunciadas por entidades ou grupos criados para apoiar os povos indígenas, como o Conselho Indigenista Missionário (Cimi) e o Conselho de Missão entre Povos Indígenas (Comin).

O presente artigo tem como objetivo analisar as denúncias de violências e violações dos direitos indígenas, especialmente, aquelas apontadas nos relatórios elaborados pelo Cimi com dados de 2014 a 2019, bem como visibilizar as resistências dos povos indígenas. Trouxemos, para dialogar com estas informações, dados produzidos junto à nossa convivência com o povo indígena Puruborá da aldeia Aperoi, ocorrida no decorrer das pesquisas de mestrado e de doutorado (2014 a $2019)^{5}$.

\section{Povo Puruborá e as pesquisas}

Puruborá é uma autodenominação que significa "[...] aquele que se transforma em onça" (MONTANHA; BARBOZA; OLIVEIRA, 2014, p. 170). Outras grafias já foram utilizadas para se referir a este povo indígena do Estado de Rondônia, entre elas, Purúborá (KOCH-GRÜNBERG, 1932), Boroburá (SNETHLAGE, 1934a, 1934b), Purú-borá (FONSECA FILHO, 1950), Puru-Borá (ROQUETTE-PINTO, 1975), Puroborá (CIMI-ANE6 , 2004).

O povo Puruborá é um povo indígena contatado, por volta de 1909, pelo Marechal Cândido Mariano da Silva Rondon (Marechal Rondon), que teria demarcado a Terra Indígena Puruborá afixando pedaços de madeiras no chão (BARBOZA, 2012; CIMI-RO, 2002; OLIVEIRA, 2015; OLIVEIRA; BRITO; BARBOZA, 2014).

\footnotetext{
${ }^{5}$ Utilizamos para a análise deste texto, os relatórios de violência contra os povos indígenas no Brasil elaborados pelo Cimi, referentes aos dados dos anos de 2014 a 2019, mesmos anos de convivência com o povo Puruborá da aldeia Aperoi.

${ }^{6}$ Conselho Indigenista Missionário-Articulação Nacional de Educação (CIMI-ANE). 
O povo Puruborá já foi considerado como isolado em 1900 por Ribeiro (1979). Na década de 2000 foi identificado como ressurgido, inicialmente, pelo Conselho Indigenista Missionário de Rondônia (CimiRO), entidade que o ajudou quando começou a se (re)agrupar, após ser expulso de seu território tradicional por três vezes.

Neste texto, empregamos o termo "ressurgido" a partir da definição de Amorim (2010): "sair do anonimato", "dar-se a conhecer", "apresentarse" e "levantar-se" como indígenas ao órgão oficial e à sociedade local, após um período sem o fazer. O "ressurgir" do povo Puruborá aconteceu, singularmente, a partir do "Encontro de Parentes Puruborá", ocorrido na aldeia Aperoi em 2001.

Após várias polêmicas nacionais a respeito do termo "ressurgido", os povos até então nomeados desta forma, após participarem do I Encontro Nacional dos Povos Indígenas em Luta pelo Reconhecimento Étnico e Territorial, que aconteceu em Olinda, Pernambuco (2003), se autodeclararam como "resistentes":

Nos debates, os povos indígenas que participaram desse Primeiro Encontro chegaram à conclusão de que devem ser reconhecidos por sua história de resistência, e não mais por uma suposta ressurgência ou emergência étnica, como vinham sendo reconhecidos os índios do Nordeste ou aqueles que foram destituídos de seus territórios e práticas culturais, religiosas, sociais, mas que, apesar de tudo, reapareceram no cenário político do indigenismo institucional, em busca de seus direitos. (AMORIM, 2010, p. 51).

No decorrer de nossa convivência com o povo Puruborá, constatamos que atualmente o povo Puruborá se autodenomina como "resistente". Depreendemos, também, que a preferência por essa denominação pode estar relacionada à ligação que o povo ainda mantém com o Cimi, posto que, durante nossa participação na Etapa Regional Rondônia da $1^{\text {a }}$ Conferência Nacional de Política Indigenista, ocorrida em 2015 em Porto Velho, Rondônia, presenciamos o posicionamento de um dos representantes do Cimi que, diante da utilização do termo "ressurgido" para se referir aos povos presentes na mesma condição dos indígenas Puruborá, gritou: "Ressurgidos não, resistentes!".

Compreendemos resistência em dois sentidos. O primeiro deles concorda com André (1988) que define resistência como a atitude de pessoas barrarem a dominação, não perderem e sim manterem suas culturas, seus costumes, suas identidades, seus conhecimentos, suas práticas, etc., apesar de um processo de oposição e morte. O segundo sentido refere-se ao processo de "camuflagem" das identidades, das culturas, dos conhecimentos, dos costumes, das práticas, etc., utilizado pelas pessoas, ao longo de um período, como forma de sobrevivência, devido ao preconceito e às constantes violências contra elas, como é o caso dos povos indígenas (CIMI, 2014).

Assim, não entendemos o termo "resistente" no sentido de "imutabilidade e inflexibilidade" e sim com o objetivo de reiterar que a 
identidade indígena Puruborá sempre esteve presente, mesmo que proibida.

Após o contato, o povo Puruborá foi praticamente dizimado por diferentes situações, entre as quais destacamos a colonização e o desenvolvimento do Estado de Rondônia, as doenças como sarampo, gripe e catapora (CIMI-RO, 2002; GALUCIO, 2005), a proibição de sua cultura - tradições, costumes, mitos, festas, língua, etc. - e as três expulsões do seu território tradicional (BARBOZA, 2012).

Consoante a Barboza (2012), a primeira expulsão do povo Puruborá de seu território tradicional ocorreu entre 1910 até 1940, face à invasão das terras desse povo indígena pela companhia Massud e Kalil. A segunda se deu em 1982, durante a delimitação da Reserva Biológica (Rebio) do Guaporé e a terceira expulsão aconteceu na década de 1990, com o processo de delimitação da Terra Indígena Uru Eu Wau Wau (BARBOZA, 2012).

Durante a última expulsão, na década de 1990, os indígenas Puruborá que ainda moravam em sua terra foram expulsos pela Fundação Nacional do Índio (Funai) por estarem na fronteira da Terra Indígena Uru Eu Wau Wau, sob a alegação de não serem indígenas, por conta da miscigenação com brancos, negros, quilombolas e bolivianos. Ignora-se nesse processo que essa miscigenação foi imposta ao longo do trabalho compelido nos seringais do rio Manoel Correia, pois o povo Puruborá foi um dos povos indígenas recrutado para extração de látex nos dois ciclos da borracha que aconteceram no Estado de Rondônia (CATHEU, 2002).

Durante esse processo, além de serem obrigadas a casar com os seringueiros da região, as indígenas Puruborá também foram cedidas como prêmios para aqueles que extraíam o maior número de látex (BARBOZA, 2012; OLIVEIRA et al., 2012).

Após as expulsões de sua terra tradicional, o povo Puruborá se dispersou por mais de onze cidades do Estado de Rondônia, bem como para fora desse Estado. Segundo Menezes (2016), a quantidade de pessoas que se autorreconhecem como indígenas Puruborá está entre 200 a 1.000 pessoas. As últimas informações de nossa pesquisa de doutorado (2019) indicam que habitam na aldeia Aperoi aproximadamente 34 pessoas e nas proximidades dela 10 pessoas.

O povo Puruborá - em especial as pessoas da aldeia Aperoi atualmente sonha, luta, mobiliza-se e resiste com o intuito de ter seus direitos materializados, sobretudo o reconhecimento identitário, a revitalização da cultura e a (re)demarcação do território tradicional.

Destacamos que utilizamos a palavra (re)demarcação porque, apesar de nunca ter sido oficialmente demarcada, durante nossa pesquisa de doutorado localizamos três mapas que apontam a existência da Terra Indígena (TI) Puruborá, além do registro histórico e coletivo do povo que confirma que ela foi demarcada por Marechal Rondon, afixando pedaços de madeiras no chão.

O primeiro mapa é de Darcy Ribeiro (1979), que apresenta a localização da área cultural indígena Puruborá. O segundo trata-se do Mapa Etno-histórico do Brasil e Regiões Adjacentes de Curt Nimuendajú (1981); e o outro é a "Carta Etnográfica da Rondônia segundo os trabalhos 
do Prof. Roquette Pinto e da Comissão Rondon de junho de 1934" (ROQUETTE-PINTO, 1975).

Nossa convivência com o povo Puruborá da aldeia Aperoi iniciou-se no decorrer da pesquisa de mestrado, do tipo etnográfico (ANDRÉ, 2004); e aprofundou-se ao longo da pesquisa de doutorado, alicerçada no materialismo histórico dialético - como método de análise, concepção de mundo e práxis (FRIGOTTO, 1989) - e em alguns elementos da pesquisa participante (BRANDÃO, 2006).

O trabalho de campo da pesquisa de mestrado aconteceu entre os dias 18 de agosto e 18 de setembro de 2014 e, posteriormente, entre os dias 09 a 16 de fevereiro de 2015. No doutorado foi possível uma permanência em campo mais extensa, distribuída em seis períodos de aproximadamente uma semana cada, durante os anos de 2016 e 2019.

As pesquisas foram desenvolvidas na aldeia Aperoi, localizada em Seringueiras, Estado de Rondônia (Mapa 1).

Mapa 1 - Mapa de localização da aldeia Aperoi.

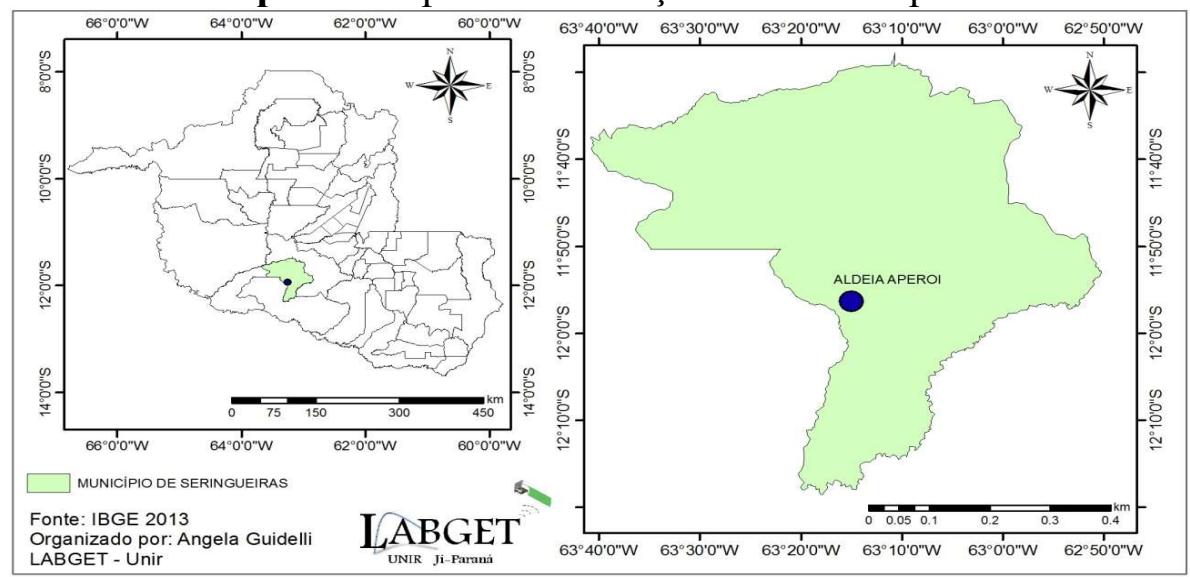

Fonte: LABGET - Unir (2013).

A aldeia Aperoi foi constituída durante a quarta assembleia anual do povo Puruborá, ocorrida em julho de 2004 (ATA DO POVO PURUBORÁ, 2004), e é formada pela soma de áreas particulares, localizadas nas margens da BR $429^{7}$, adquiridas por alguns indígenas Puruborá após as expulsões. Logo, a aldeia Aperoi não está situada em território indígena oficialmente demarcado.

Para a realização das pesquisas de mestrado e de doutorado foram adotados os procedimentos éticos recomendados pelo Conselho Nacional de Saúde (CNS) para os estudos que envolvem seres humanos, indicados nas Resoluções 466/2012 e 510/2016. Consequentemente, nos anos de 2014 e 2016, as pesquisas de mestrado e doutorado, respectivamente, foram aprovadas pelos Comitês de Ética em Pesquisa (CEP) das instituições a que estávamos vinculados - Fundação Universidade Federal de Rondônia (UNIR) e Universidade Federal de Mato Grosso (UFMT) - e pela Comissão Nacional de Ética em Pesquisa (CONEP).

\footnotetext{
${ }^{7}$ Rodovia federal que liga alguns municípios do Estado de Rondônia, entre eles: Presidente Médici, Alvorada do Oeste, São Miguel do Guaporé, Seringueiras, São Francisco do Guaporé, São Domingos e Costa Marques à BR 364, que liga a região Norte às demais regiões do país. 
A pesquisa empírica contou com os seguintes instrumentos: a) observação participante realizada nos anos de 2014 a 2019, registrada em diário de campo, fotografias e vídeos; b) análise dos relatórios de violência contra os povos indígenas no Brasil elaborados pelo Cimi (dados de 2014 a 2019); e c) entrevista semiestruturada realizada com a cacique Hozana em 2014. A análise ocorreu a partir da triangulação dos dados produzidos pelos instrumentos utilizados, a finalidade deste texto e o referencial teórico empregado.

Este texto está organizado em três seções. Na primeira, nos debruçamos sobre as resistências dos povos indígenas do Brasil, dando ênfase a resistência do povo Puruborá da aldeia Aperoi - RO. Na segunda, analisamos as violências e violações dos direitos indígenas do Brasil e do povo Puruborá da aldeia Aperoi - RO, sobretudo, aquelas apontadas nos relatórios de violência contra os povos indígenas no Brasil, elaborados pelo Cimi com dados de 2014 a 2019. A seguir, tecemos as considerações finais possíveis nesse momento.

\title{
$O$ conflito pela terra e a divergência de perspectivas: as resistências dos povos indígenas do Brasil e os Puruborá da aldeia Aperoi - RO
}

Desde os primeiros contatos entre indígenas e europeus houve conflitos, lutas e resistências por parte dos povos indígenas que, embora inicialmente tenham se "encantado" com os povos que vieram do mar e mantiveram um "bom relacionamento", posteriormente, resistiram às suas práticas violentas e genocidas. Prezia (2017, p. 29, grifos do autor) afirma que:

\begin{abstract}
O bom relacionamento entre indígenas e portugueses durou enquanto os europeus não se preocuparam em ocupar a terra. Quando o rei de Portugal passou a doar grandes lotes do território - as capitanias hereditárias -, a membros da pequena nobreza e a comerciantes que desejassem estabelecer-se na colônia, essa harmonia acabou. Os indígenas reagiam e as lutas e guerras multiplicaram-se, sobretudo no litoral, onde foram instaladas as vilas e os engenhos de açúcar. Aquela "Terra sem males" tornava-se uma "Terra dos males sem fim", com muito sofrimento e morte... Iniciava-se também o período da grande resistência indígena.
\end{abstract}

Assim, percebemos que o conflito pela terra foi o "divisor de águas" no relacionamento harmonioso entre indígenas e europeus. Nessa perspectiva, Mariátegui (2010) postula que o problema indígena é um problema econômico-social e se identifica primeiramente com o problema da terra e os estudos e as pesquisas que não consideram esse elemento estão "[...] condenados a um descrédito absoluto" (p. 53). 
Segundo o autor, na realidade peruana, a república, que deveria elevar a condição dos e das indígenas,

[...] pauperizou o índio, agravou sua prostração e exacerbou sua miséria. A República significou, para os índios, a ascensão da nova classe dominante que se apropriou sistematicamente das suas terras. Numa raça de costumes e de alma agrárias, como a raça indígena, esta privação constituiu uma causa de dissolução material e moral. A terra sempre foi a alegria do índio. 0 índio casou-se com a terra. Sente que "a vida vem da terra" e volta à terra. Por isso, o índio pode ser indiferente a tudo, menos à posse da terra, que suas mãos e seus esforços lavram e fecundam laboriosamente. (MARIÁTEGUI, 2005, p. 86, grifo do autor).

E sabemos que essa realidade não é apenas peruana, apesar das especificidades de cada povo indígena. Nesse sentido, enquanto para os e as indígenas a terra é território, é Pacha Mama (Mãe Terra), na sociedade capitalista a terra se transfigura em mercadoria, implicando alterações sociais, econômicas, culturais e políticas que afetaram e ainda afetam diretamente os povos indígenas.

A perspectiva de desenvolvimento, fundamentada na lógica de crescimento econômico sem regras e alicerçado na exploração e na exaustão dos recursos naturais, por um lado, e a terra como território e Pacha Mama, por outro, expressam concepções diversas e antagônicas entre a sociedade capitalista e os povos indígenas, respectivamente. À vista disso, os povos indígenas são considerados um impasse ao desenvolvimento e progresso do país por priorizarem as pessoas, a natureza e os demais seres vivos.

De um lado, a perspectiva capitalista é a de exploração, grilagem e invasão das terras indígenas, do crescimento ilimitado, do consumo contínuo de mercadorias, de padronização de produtos, da concentração de redes de coleta e de comercialização, da exploração da força de trabalho de homens e mulheres, do acesso e aumento de financiamentos e créditos destinados ao agronegócio, à mineração, às hidrelétricas, às pesquisas de sementes transgênicas etc., da expulsão e eliminação dos povos indígenas, uma vez que "atrapalham o crescimento econômico" etc. (RAMOS et al., 2018).

Por outro lado - dos povos indígenas -, a defesa é pela conservação das diversidades biológicas e das diferenças culturais, pelo território e pela manutenção dos ecossistemas, pela proibição e eliminação do desmatamento, pela existência e liberdade de utilização das sementes crioulas, pela proibição da extração de madeiras etc. (RAMOS et al., 2018).

Brighenti (2015, p. 20, grifos do autor) declara que:

Os povos indígenas no Brasil estão enfrentando centenas de conflitos com grandes e médias obras que provocam 
modificações radicais em seus territórios e modos de vida tradicional. Convencionou-se relacionar esses empreendimentos ao "desenvolvimento", porque o setor mais privilegiado da sociedade brasileira defende que eles geram riquezas e empregos e promovem 0 "progresso". Independentemente do tamanho e do montante dos recursos envolvidos, seus efeitos são devastadores sobre espaços considerados sagrados por essas populações. Das Pequenas Centrais Hidrelétricas $(\mathrm{PCH})$ aos megaprojetos, que envolvem bilhões de reais, os impactos sobre as populações que habitam esses espaços há milhares ou centenas de anos são severos e, na maioria dos casos, irreversíveis. Em muitos casos, elas são forçadas à remoção e obrigadas a deixar para trás suas fontes históricas de sobrevivência, como a pesca e o extrativismo.

A partir desses e de outros conflitos de classe, existem, além da invasão das terras indígenas, a perseguição e a violência contra os mesmos, por estes produzirem suas existências em contraposição ao modo de produção capitalista, seus valores e toda sua lógica: "As violências contra os povos indígenas em nosso país são avassaladoras. A dor, as ameaças, as invasões, as torturas, as agressões cotidianas expressam as condições a que os povos indígenas continuam sendo submetidos" (KRÄUTLER, 2015, p. 10).

Porém às agressões constantes e contínuas também se instituem resistências dos povos indígenas cotidianamente e, conforme Thompson (1998), também percebemos que elas acontecem de forma explícita, direta ou aberta, ou, de maneira implícita, indireta ou dissimulada. Em harmonia com Ramos et al. (2018, p. 211$)$ :

Faz parte do primeiro grupo de resistência as mobilizações em Brasília, nos estados e em diversos municípios do país, ocupações de fazendas, organização e mobilização para fechar rodovias, elaboração de documentos, inclusive de denúncias, a Produção Associada e agroecológica, a luta e mobilização pelos direitos legalmente conquistados, entre outros.

As fotografias 1 e 2 exemplificam as manifestações de resistência explícita dos povos indígenas contra o agronegócio e sua lógica, contra as mudanças no procedimento de demarcação das terras indígenas, enfim, contra o retrocesso dos direitos indígenas. 
Fotografias 1 e 2 - Manifestações de resistência explícita dos povos indígenas no Brasil.

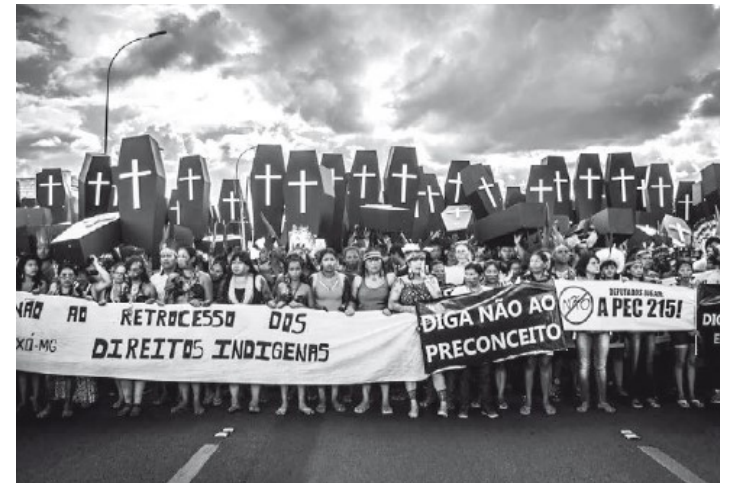

Fonte: Articulação dos Povos Indígenas do

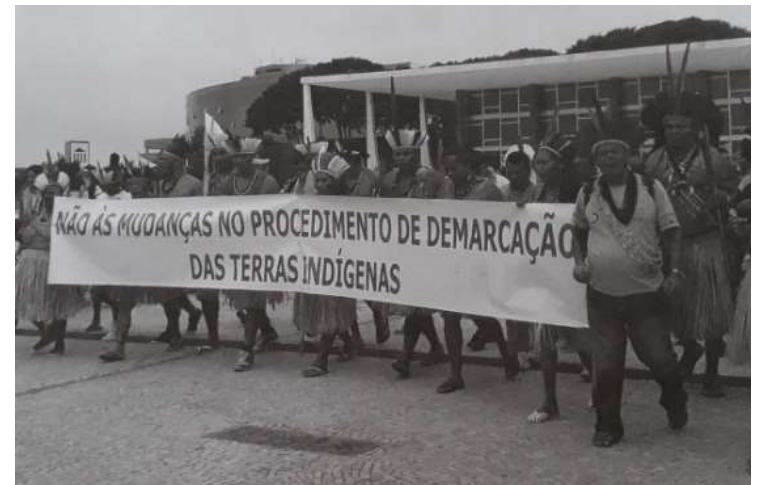

Fonte: Laila Menezes (CIMI, 2015, p. 36).

Brasil (APIB) (CIMI, 2018, p. 18).

As e os indígenas Puruborá moradores da aldeia Aperoi e dos diversos municípios do Estado de Rondônia também participam frequentemente de manifestações de resistência, seja de forma explícita ou de maneira dissimulada. Durante nossa convivência com as e os Puruborá da aldeia Aperoi acompanhamos várias manifestações de resistência, especificadamente, das mulheres Puruborá.

Entre as últimas manifestações de resistência explícita que as mulheres participaram, destacamos a primeira Marcha das mulheres indígenas - ocorrida em Brasília, Distrito Federal entre os dias 9 a 14 de agosto de 2019 - e a mobilização na Câmara dos Deputados contra os Projetos de Emenda à Constituição (PECs) 187/2016 e 343/20179 .

Nessa última manifestação, a cacique Hozana Puruborá esteve presente lutando contra as PECs recém referidas. Hozana Puruborá é a mulher de camiseta amarela com a mensagem "A causa indígena é de todos nós" que aparece nas fotografias 3 e 4 . Ao nos encaminhar via WhatsApp a fotografia 4 no dia 23 de agosto de 2019 , escreveu: "botando os ruralistas no devido lugar".

\footnotetext{
${ }^{8}$ Permite explicitamente às comunidades indígenas praticar atividades agropecuárias e florestais em suas terras, bem como comercializar aquilo que foi produzido e gerenciar sua renda, o que já é possível e ocorre nas terras indígenas.

${ }^{9}$ Aponta as propostas de arrendamento das terras indígenas para fazendeiros e exploração de recursos minerais e hídricos de terras demarcadas, sem participação ou consulta às populações da área, apenas com a autorização da Funai.
} 
Fotografias 3 e 4 - Participação Puruborá na mobilização na Câmara dos Deputados contra os PECs 187/2016 e 343/2017 (2019).

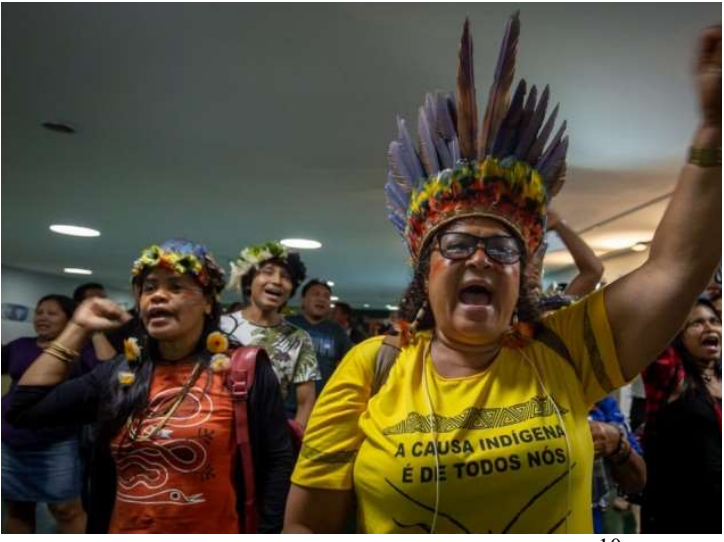

Fonte: Tiago Miotto/Cimi (2019a) ${ }^{10}$.

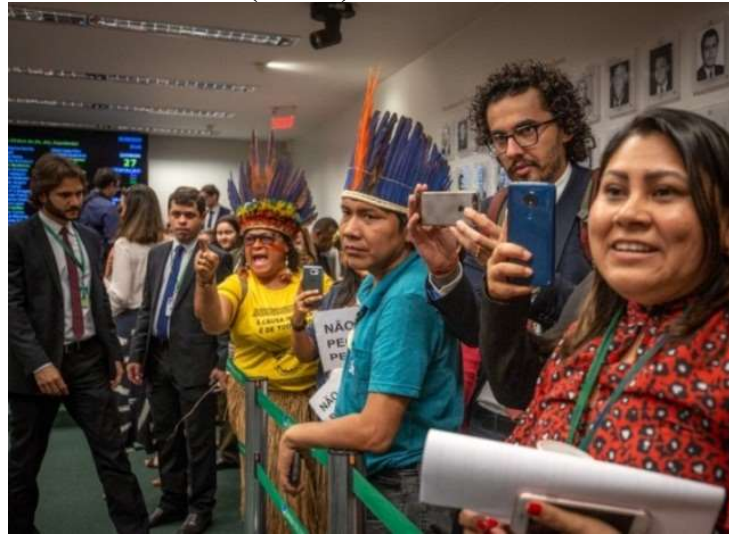

Fonte: Hozana Puruborá (2019).

Ramos et al. (2018) caracterizam como manifestações da resistência dissimulada, as lutas que vários povos e comunidades tradicionais, entre eles, os povos indígenas, travam para não serem "incorporados" pela sociedade capitalista. As autoras e os autores citam como exemplos deste tipo de resistência:

[...] a) o resgate de práticas culturais e costumeiras, por parte de diversos povos e comunidades tradicionais que foram expropriados delas $[\ldots]$; b) a produção de alimentos e venda em feiras; c) ao aceitar um convite de reunião de um representante do poder (político, padre, diretor ou diretora escolar etc.) e negá-lo ao não comparecer; d) ao trocar seus produtos sem a utilização do dinheiro; e) a produção a partir de sementes crioulas e não por sementes transgênicas ou convencionais; f) ao manter a produção agroecológica; [...]. (RAMOS et al., 2018 , p. 212, grifo das autoras e dos autores).

O povo Puruborá da aldeia Aperoi também manifesta as resistências dissimuladas, por exemplo, através do resgate das práticas culturais (língua, pintura tradicional, mitos, etc.) junto aos anciãos do povo que não residem na aldeia e da transmissão para as pessoas da comunidade e fora dela por meio da escola do povo, das atividades cotidianas, das assembleias anuais, etc.; e da manifestação acontecida no interior da aldeia contra a votação do projeto do marco temporal ${ }^{11}$ ocorrida em 2017 , que deu origem às festas tradicionais que acontecem anualmente na aldeia.

\footnotetext{
10 Fotografia disponível em: https://cimi.org.br/2019/08/abertura-de-terras-indigenas-para-exploracaosera-retirada-de-pec-187-apos-mobilizacao/. Acesso em: 07 set. 2019.

${ }^{11} \mathrm{O}$ "marco temporal" visa impor a necessidade da presença dos povos e das comunidades na posse da terra à data de 5 de outubro de 1988 ou, caso nelas não estivessem, impor a regra de que deveriam estar postulando-as judicialmente ou disputando-as fisicamente - o chamado renitente esbulho. Os povos que não atendem a estas condições perderiam o direito à demarcação da área reivindicada. (RANGEL; LIEBGOTT, 2017, p. 15, grifo da autora e do autor).
} 
No dia da votação desse projeto do marco temporal, segundo informações obtidas com Camila Puruborá, as pessoas da comunidade se reuniram na aldeia Aperoi - em frente à casa de Dona Emília, matriarca do povo, falecida em 2013 - para fazer uma manifestação contra o marco temporal que acabou se tornando o início das festas tradicionais do povo. Além das e dos Puruborá, se fizeram presente os e as cônjuges e indígenas de outras etnias, como Migueleno, Cujubim e Gavião, que conversaram sobre o assunto e os direitos indígenas (DIÁRIO DE CAMPO, 16/08/2017).

Assim, julgamos que as tensões, os conflitos, as lutas e as resistências indígenas revelam alguns problemas enfrentados pelos povos indígenas no Brasil. Entre eles, estão as violências e violações dos direitos das e dos indígenas, inclusive aquelas denunciadas pelo Cimi nos relatórios de violência contra os povos indígenas no Brasil. A seguir, analisamos os dados de 2014 a 2019, apontados nesses relatórios, destacando a realidade do povo Puruborá.

\section{Violências e violações de direitos: indígenas do Brasil e o povo Puruborá da aldeia Aperoi - RO}

O relatório de violência contra os povos indígenas no Brasil, dados de 2014 a 2019, elaborado pelo Cimi, indica quatro tipos de violências: a) violência contra a pessoa; b) violência contra o patrimônio; c) violências provocadas por omissão do poder público; e d) violência contra povos indígenas isolados e de pouco contato.

Os dados apresentados por esses relatórios são alarmantes e ratificam as violências que os povos indígenas de nosso país têm enfrentado cotidianamente. Fundados nesses relatórios, produzimos os quadros 1,3 e 7 , que demonstram o que temos denunciado até 0 momento ${ }^{12}$. A seguir, discorremos sobre cada tipo de violência citada pelo Cimi, trazendo dados produzidos durante nossa convivência com o povo Puruborá da aldeia Aperoi.

\section{Violência contra a pessoa}

Os dados apontados no quadro a seguir causam preocupação, confirmando as violências contra a pessoa que as e os indígenas brasileiros têm enfrentado. Entre elas ressaltamos, o abuso de poder, a ameaça de morte e várias, o assassinato, a tentativa de assassinato, o homicídio culposo, as lesões corporais dolosas, o racismo e a discriminação étnico-culturais e a violência sexual (CIMI, 2015; 2016; 2017; 2018; 2019b; 2020).

\footnotetext{
${ }^{12}$ Para maiores informações acerca dos números, dos Estados e dos povos que são sujeitos dessas violações e violências, acessar os relatórios referidos na íntegra.
} 
Quadro 1 - Violência contra a pessoa - Dados de 2014 a 2019.

\begin{tabular}{|lcccccc|}
\hline \multicolumn{1}{|c}{ Tipos de violência / ano } & $\mathbf{2 0 1 4}$ & $\mathbf{2 0 1 5}$ & $\mathbf{2 0 1 6}$ & $\mathbf{2 0 1 7}$ & $\mathbf{2 0 1 8}$ & $\mathbf{2 0 1 9}$ \\
\hline Abuso de poder & 16 & 8 & 8 & 8 & 11 & 13 \\
\hline Ameaça de morte & 29 & 12 & 10 & 14 & 8 & 33 \\
\hline Ameaças várias & 27 & 25 & 7 & 18 & 14 & 34 \\
\hline Assassinato & 67 & 52 & 56 & 59 & 48 & 113 \\
\hline Homicídio culposo & 20 & 18 & 11 & 19 & 18 & 20 \\
\hline Lesões corporais dolosas & 18 & 12 & 11 & 12 & 5 & 13 \\
\hline $\begin{array}{l}\text { Racismo e discriminação } \\
\text { culturais }\end{array}$ & 19 & 13 & 17 & 18 & 17 & 16 \\
\hline Tentativa de assassinato & & & & & & \\
\hline Violência sexual & 31 & 31 & 23 & 27 & 22 & 25 \\
\hline Total de casos & 18 & 9 & 13 & 16 & 15 & 10 \\
\hline
\end{tabular}

Fonte: Construído pelos autores com base nos relatórios de violência contra os povos indígenas no Brasil - dados de 2014 a 2019 (CIMI, 2015; 2016; 2017; 2018; 2019b; 2020).

Entre tantas outras questões, o quadro 1 evidencia o grande número de casos de assassinatos, que, inicialmente diminuiu nos anos 2014 a 2018 e cresceu mais de $135 \%$ no ano de 2019 . Os assassinatos ocorreram em decorrência de vários motivos, entre eles, as brigas e 0 conflito fundiário (CIMI, 2015; 2016; 2017; 2018; 2019b; 2020).

Faz-se necessário salientar que a quantidade de vítimas das violências contra a pessoa pode ser mais expressiva, considerando que o relatório de 2014 traz também os dados da quantidade de vítimas dentro dos casos: mais de 1.642 pessoas foram vítimas nos 245 casos registrados de violência contra a pessoa.

Destarte, 108 pessoas foram vítimas de abuso de poder; 161 de ameaça de morte; 910 de ameaças várias; 70 de assassinato; 20 de homicídio culposo; 51 de lesões corporais dolosas; 295 de tentativa de assassinato e 27 de violência sexual (CIMI, 2015).

No ano de 2015, 54 pessoas foram vítimas dos 52 casos de assassinato (CIMI, 2015) e no ano de 2017, 68 pessoas foram vítimas dos 59 casos de assassinato e 22 pessoas dos 19 casos de homicídio culposo (CIMI, 2016). Já no ano de 2018,50 pessoas foram vítimas dos 48 casos de assassinato, 19 pessoas dos 18 casos de homicídio culposo e 53 pessoas dos 22 casos de tentativa de assassinato (CIMI, 2019b).

Fotografias 5 e 6 - “Seu” Querino Kaingang, vítima de tiroteiro (2018).

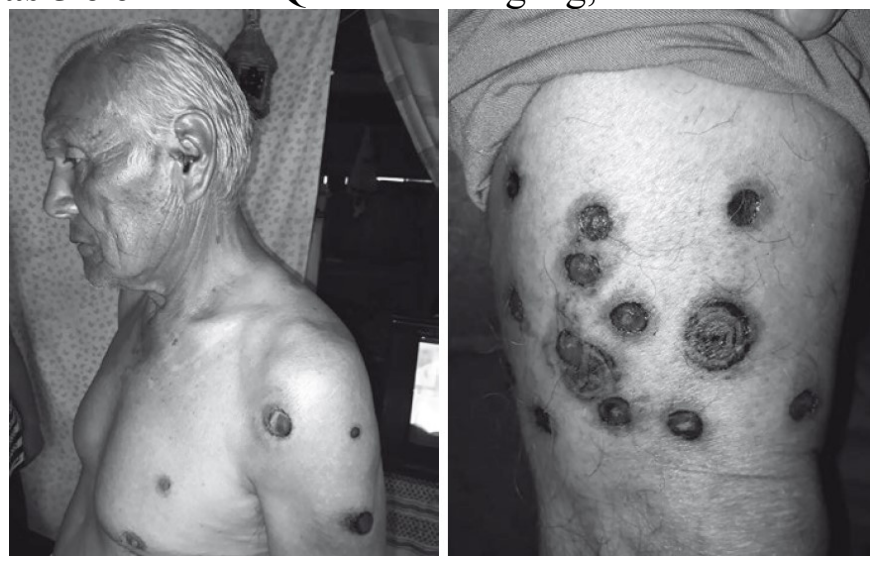

Fonte: Comunidade Kaingang (CIMI, 2019b, p. 89). 
As fotografias 5 e 6 evidenciam um caso de lesão corporal vivenciado por "Seu" Querino Kaingang em fevereiro de 2018, o qual estava juntamente com um grupo Kaingang que retomou uma área de terra que seria de propriedade do Estado do Rio Grande do Sul, conhecida como Fazenda da Brigada Militar. De acordo com o Cimi (2019b, p. 89):

Em reação a esta mobilização, sem nenhum mandado da Justiça Federal que autorizasse tal ação, a Brigada Militar atacou e, de forma brutal, retirou, à força, as famílias Kaingang do local, onde haviam montado 0 acampamento.

A violenta ação causou, além do pânico, medo nas crianças e mulheres, ferimentos em muitos indígenas, especialmente em um idoso com mais de 80 anos, que foi preso. Os ferimentos provocados pelos brigadianos foram causados por balas de borracha, bombas de efeito moral e até bala letal. Os relatos dos indígenas comprovam a brutalidade e a violência empregadas pelos efetivos de policiais.

Os dados do Cimi apresentam vários casos de assassinatos no decorrer dos relatórios. Porém, trouxemos como ilustração apenas um desses casos, causado por conflito fundiário, ocorrido na Bahia:

Na Terra Indígena Tupinambá de Olivença, indígenas estavam em suas casas, numa área retomada na comunidade Serra das Trempes, próximo à estrada, quando pistoleiros invadiram a aldeia, atirando e destruindo tudo. No momento do ataque, a vítima estava dormindo e não conseguiu fugir, sendo assassinada com mais de 20 tiros. (CIMI, 2015, p. 76).

Esse é o relato de um dos 395 casos de assassinatos ocorridos nos anos de 2014 a 2019. Acentuamos que desse total, 113 aconteceram apenas no ano de 2019 , representando mais de $28,5 \%$ do total de casos dos últimos seis anos. Rangel e Liebgott (2020) denunciam que esse aumento dos casos de assassinato e outras violências (intolerância, racismo, omissão e negligência estatal, invasões dos territórios, agressões físicas, ameaças, etc.) contra os povos indígenas evidenciados pelos quadros 1,3 e 7 construídos por nós, a partir dos referidos relatórios, se efetiva por causa da lógica de pensamento do então presidente Jair Bolsonaro, alicerçada na desqualificação dos indígenas enquanto sujeitos de direito, na desvalorização das formas e dos processos de produção dos indígenas, fortalecendo estereótipos contra eles (improdutivo, indolente e obsoleto) e na desumanização da pessoa do indígena, reativando-o como um estorvo, empecilho e um problema a ser removido da sociedade.

Advertimos que, pensar que essa lógica é forjada tão somente a partir da posição expressa por uma única pessoa é ingenuidade, pois se 
faz necessário compreender que ela é gestada e compartilhada por um número expressivo de pessoas que dão sustentação ao atual presidente da República. Logo, ele é o protagonista dessas ideias.

Além do significativo número de assassinatos e tentativas de assassinatos, verificamos a grande quantidade de ameaças - de morte e várias - a que os povos indígenas são submetidos. Em 2015, o relatório de violência contra os povos indígenas registrou um caso de ameaças verbais contra a cacique do povo Puruborá, consoante o exposto no quadro 2.

Quadro 2 - Violência contra a pessoa - realidade Puruborá (2015).

\section{MAIO/2015}

VÍTIMA: Hozana M. de Oliveira Puruborá

POVO: PURUBORÁ

TERRA INDÍGENA: PUROBORÁ

MUNICÍPIO: SERINGUEIRAS

LOCAL DA OCORRÊNCIA: Seringueiras

DESCRIÇÃO: A liderança recebeu ameaças de moradores que vivem no entorno da terra indígena, que está em processo de demarcação. Em anos anteriores essa liderança teve que se retirar de sua terra devido às seguidas ameaças contra a sua integridade física. $\mathrm{O}$ programa Terra Legal incide diretamente sobre o território reivindicado pelo seu povo, e os moradores se sentem prejudicados.

MEIO EMPREGADO: Ameaças verbais

Com informações de: Cimi Regional

Fonte: Cimi (2016, p. 108, grifos do autor).

Em entrevista, durante nossa pesquisa de mestrado, Hozana afirmou que teve que se retirar de sua terra em face às ameaças recebidas:

Eu trabalhava na cidade, em Seringueiras e eu estava sendo ameaçada pelos fazendeiros. Aí fui pra Porto Velho ${ }^{13}$. Fiquei em Porto Velho pra ninguém saber onde eu tava, fiquei quase bem dizer, bem dizer não, eu fiquei escondida lá. Quatro meses trabalhando lá em Porto Velho. Aí eu achei que não tava certo eu ficar lá e minha família aqui. As minhas filhas, meu marido, ficaram aqui, minha mãe. (Entrevista Hozana, 04/09/2014).

Nessa perspectiva, desde a convivência durante nossa pesquisa de mestrado, conhecemos e presenciamos que as e os Puruborá da aldeia Aperoi vivenciam vários momentos de tensão, devido às ameaças desferidas a elas e eles, notadamente, durante as assembleias que o povo Puruborá realiza anualmente em favor de seus direitos, especialmente, o de (re)demarcação do seu território tradicional.

Em uma de nossas estadias na aldeia, às 12h50min, estávamos sentados na área da casa de Hozana e chegou um senhor ${ }^{14}$ procurando por ela. Dissemos a ele que iríamos chamá-la. Quando entramos na

\footnotetext{
${ }^{13}$ Capital do Estado de Rondônia.

${ }^{14}$ Era a primeira vez que ele tinha aparecido na aldeia após nossa chegada.

RAMOS, Anatália Daiane de Oliveira; ZIBETTI, Marli Lúcia Tonatto; CAETANO, Edson. Violências e resistências: povos indígenas do brasil e o povo Puruborá da aldeia Aperoi - RO. Espaço Ameríndio, Porto Alegre, v. 15, n. 2, p. 206-238, mai./ago. 2021.
} 
casa para chamar Hozana, sua filha Gisele - que na época residia na aldeia Aperoi e era professora contratada da Escola Indígena Estadual de Ensino Fundamental Ywará Puruborá15 - , perguntou quem era e respondemos que se tratava de um senhor à procura de sua mãe. Dirigindo-se à janela da frente da casa, Gisele indagou ao senhor o nome dele e o que o mesmo desejava (DIÁRIO DE CAMPO, 06/09/2014).

Somente após a resposta, Gisele foi até os fundos da casa, onde Hozana estava e perguntou: "Mãe você conhece um homem com nome de Maia?". Hozana respondeu que sim. "Então vai lá na frente que ele está querendo falar contigo" - disse Gisele. Hozana disse: "É muito amigo do seu pai", dirigindo-se à frente da casa (Informação verbal, DIÁRIO DE CAMPO, 06/09/2014).

Em seguida Gisele orientou-nos a não informar para qualquer pessoa que sua mãe estava em casa, pois Hozana recebia muitas ameaças de morte e para um "doido" chegar e matar sua mãe não custava nada. A mesma nos informou que a Polícia Federal permaneceu em sua casa por um tempo, devido às ameaças decorrentes da luta pela demarcação oficial do território tradicional Puruborá e que durante a realização de assembleias era necessário até contar com proteção policial (DIÁRIO DE CAMPO, 06/09/2014).

\section{Violência contra o patrimônio}

Inicialmente destacamos que, para o Cimi (2015, p. 44), o patrimônio indígena "[...] é composto pela terra em sua dimensão territorial e em seus usos de acordo com as normas e os costumes das sociedades indígenas". Nessa sequência, a natureza, os cemitérios, as roças, as sementes, os sítios arqueológicos, as edificações tradicionais, as escolas, os postos de saúde, entre outros, constituem o patrimônio indígena (CIMI, 2015; 2016; 2017; 2018; 2019b; 2020).

Entretanto, além dos bens materiais, os bens imateriais também fazem parte desse patrimônio. Entre eles, frisamos os saberes tradicionais, as línguas indígenas, os rituais, as danças, as expressões religiosas, as músicas e as pinturas. Todos esses são direitos autorais, de imagem e intelectual das e dos indígenas (CIMI, 201 5; 2016; 2017; 2018; 2019b; 2020).

No quadro a seguir fica evidente o número significativo de violências contra o patrimônio indígena. As omissões e a morosidade na regularização de terras indígenas aumentaram no decorrer dos anos, exceto no ano de 2018 , em relação ao ano anterior. O Cimi (2019b, p. 34) assegura que esses dois tipos de violências "[...] são relacionados quase que exclusivamente à União, embora haja, efetivamente, outros aspectos que contribuem para que os direitos indígenas, constitucionalmente estabelecidos, não sejam assegurados".

\footnotetext{
${ }^{15}$ Escola do povo Puruborá localizada na aldeia Aperoi e criada pelo Decreto Estadual no 11.746 de 8 de agosto de 2005.
} 
Quadro 3 - Violência contra o patrimônio - Dados de 2014 a 2019.

\begin{tabular}{|lccccccc|}
\hline Tipos de violência/Ano & $\mathbf{2 0 1 4}$ & $\mathbf{2 0 1 5}$ & $\mathbf{2 0 1 6}$ & $\mathbf{2 0 1 7}$ & $\mathbf{2 0 1 8}$ & $\mathbf{2 0 1 9}$ \\
\hline $\begin{array}{l}\text { Omissão e morosidade na regularização de } \\
\text { terras }\end{array}$ & 118 & 654 & 836 & 847 & 821 & 829 \\
\hline Conflitos relativos a direitos territoriais & 19 & 18 & 12 & 20 & 11 & 35 \\
\hline $\begin{array}{l}\text { Invasões possessórias, exploração ilegal de } \\
\text { recursos naturais e danos diversos } \\
\text { patrimônio }\end{array}$ & $\mathbf{a o}$ & 55 & 59 & 96 & 111 & 256 \\
\hline Total de casos & $\mathbf{2 2 1}$ & $\mathbf{7 2 7}$ & $\mathbf{9 0 7}$ & $\mathbf{9 6 3}$ & $\mathbf{9 4 3}$ & $\mathbf{1 . 1 2 0}$ \\
\hline
\end{tabular}

Fonte: Construído pelos autores a partir dos relatórios de violência contra os povos indígenas no Brasil - dados de 2014 a 2019 (CIMI, 2015; 2016; 2017; 2018; 2019b; 2020).

A situação das terras indígenas no Brasil pode ser compreendida a partir dos dados expressos pela figura 1 na qual se observa que 41,29\% das terras indígenas do Brasil estão sem providências, ou seja, a terra foi reivindicada pela comunidade indígena, mas não houve nenhuma medida administrativa para sua regularização - $12,48 \%$ das terras indígenas estão a identificar, como é o caso do povo Puruborá.

Figura 1 - Situação geral das terras indígenas no Brasil.

\begin{tabular}{|c|c|c|}
\hline Situaçáo geral* & Quant. & $\%$ \\
\hline $\begin{array}{l}\text { Registradas: demarcação concluída e registrada no Cartório de Registro de Imóveis da Comarca e/ou no } \\
\text { Serviço de Patrimônio da União (SPU) }\end{array}$ & 408 & 31,43 \\
\hline Homologadas: com Decreto da Presidência da República. Aguardando registro. & 14 & 1,08 \\
\hline Declaradas: com Portaria Declaratória do Ministério da Justiça. Aguardando homologaçăo. & 63 & 4,85 \\
\hline $\begin{array}{l}\text { Identificadas: reconhecidas como território tradicional por Grupo de Trabalho da Funai. Aguardando } \\
\text { Portaria Declaratória do Ministério da Justiça. }\end{array}$ & 48 & 3,70 \\
\hline $\begin{array}{l}\text { A identificar: incluídas na programaçăo da Funai para futura identificaçăo, com Grupos de Trabalho técnicos } \\
\text { já constituidos. }\end{array}$ & 162 & 12,48 \\
\hline $\begin{array}{l}\text { Sem providências: terras reivindicadas pelas comunidades indigenas sem nenhuma providência } \\
\text { administrativa para sua regularizaçăo. }\end{array}$ & 536 & 41,29 \\
\hline Reservadas: demarcadas como "reservas indigenas" à época do Serviço de Proteção aos İndios (SPI). & 40 & 3,08 \\
\hline $\begin{array}{l}\text { Com portaria de restriçào: terras que receberam portaria da Presidência da Funai restringindo o uso da } \\
\text { área ao direito de ingresso, locomoçáo ou permanência de pessoas estranhas aos quadros da Funai. }\end{array}$ & 6 & 0,46 \\
\hline Dominial: de propriedade de comunidades indigenas. & 21 & 1,62 \\
\hline Total & 1.298 & 100 \\
\hline
\end{tabular}

"Os dados listados tem como fontes: comuntdades indigenas, o Ctm1 e a Funat.

Fonte: Cimi (2020, p. 53).

Desde agosto de 2016, a partir do governo de Michel Temer, nenhuma terra indígena foi homologada, considerando que a única homologação assinada pelo então presidente foi suspensa por decisão judicial (CIMI, 2020). No atual governo, de Jair Bolsonaro, "[...] nenhum centímetro de terra foi demarcado ou titulado para os povos indígenas e as comunidades quilombolas" (CIMI, 2020, p. 51).

Oliveira e Buzatto (2020) e Rangel e Liebgott (2020) denunciam que o governo de Jair Bolsonaro é marcado pela não efetivação dos direitos 
dos povos indígenas reconhecidos formalmente em vários documentos como, por exemplo, a Constituição Federal de 1988. Consoante a Oliveira e Buzatto (2020, p. 12) "É fato que o governo não tem interesse no diálogo com os povos indígenas e tem vociferado contra as demarcações e a regularização dos territórios indígenas".

As denúncias de omissões e morosidade na regularização de terras indígenas têm sido feitas pelos povos indígenas do Brasil, entre eles, o povo Puruborá. Em todos os relatórios, a terra desse povo indígena do Estado de Rondônia foi alvo de reivindicação. Como evidencia o quadro 4, a terra indígena Puruborá é uma das três terras indígenas do Estado de Rondônia que está em processo de identificação: Cujubim do Rio Cautário, Migueleno (Rio São Miguel) e Puruborá do Rio Manuel Correia (CIMI, 2020). Nesta etapa, segundo o Cimi (2016; 2017; 2018; 2019b; 2020) a Funai cria um Grupo Técnico (GT) para averiguar se a área reivindicada pelo povo indígena se constitui enquanto terra tradicional indígena, ou seja, está inserida na programação da Funai para futura identificação, com GT já constituído.

Quadro 4 - Violência contra o patrimônio - morosidade na regularização da terra indígena Puruborá (2014).

TERRA INDÍGENA: PURUBORÁ

POVO: PURUBORA

TIPO DE DANO/CONFLITO: Morosidade no processo demarcatório

DESCRIÇÃO: A Funai iniciou os estudos para demarcação da terra em 2000. No entanto, o procedimento foi paralisado. Em 2010 foi retomado, mas paralisado logo em seguida. Enquanto isso, a comunidade vem sendo ameaçada pela ação de invasores, especialmente de madeireiros, que derrubam as castanheiras existentes dentro da terra indígena.

FONTE: Cimi Regional Rondônia

Fonte: Cimi (2015, p. 54, grifos do autor).

A terra indígena Puruborá significa mais que um espaço geográfico para produzir a vida. Em conformidade com Oliveira, Brito e Biazatti (2012, p. 9-10):

[...] os povos indígenas têm uma relação muito forte com seus territórios porque através dele reforçam sua identidade enquanto povos indígenas, já que esses espaços são carregados de simbolismo e são permeados por uma relação de afetividade que garante entre outras coisas a unidade grupal. Neste sentido, a demarcação do território dos Puruborá, significa muito mais do que dispor de um espaço do qual detenham a posse, já que segundo um dos entrevistados não deixaria as suas terras nem que Ihe fosse oferecido um emprego com um ótimo salário na cidade.

Identificamos que um dos elementos aglutinadores do povo Puruborá é a questão territorial. Oliveira, Brito e Biazatti (2012, p. 9) reconhecem que "A demarcação do território do povo Puruborá está estreitamente ligada ao resgate e revitalização da cultura, bem como da autoestima e da identidade deste povo". 
Entretanto, não diferente de outros povos indígenas do país, como mostrado nos quadros 3 e 4 e na figura 1, a situação do povo Puruborá é de espera: o último GT constituído para realização de estudos complementares necessários à identificação e delimitação da Terra Indígena Puruborá foi coordenado pelo antropólogo Felipe Ferreira Vander Velden da Universidade Federal de São Carlos (UFSCar) - Portaria $\mathrm{n}^{\circ} 1.061$, de 11 de setembro de 2014. Desde então, percebemos que o processo de identificação e delimitação da TI Puruborá avançou pouco e atualmente está parado, de acordo com as e os participantes de nossa pesquisa de doutorado.

O quadro 3 demonstra que os conflitos relativos a direitos territoriais diminuíram até o ano de 2016 e aumentaram significativamente no ano de 2017, comparado com o ano anterior, voltando a sofrer redução no ano de 2018, porém voltando a crescer muito em 2019. Um dos casos mencionados pelo Cimi (2019b, p. 53) é o do povo indígena Tremembé do Maranhão:

[...] três jagunços armados entraram no território Tremembé, ameaçando e causando terror. São 60 famílias que vivem em 86 hectares desde seus ancestrais Tremembé. Mesmo que tenha sido constatada fraude na veracidade dos títulos do suposto proprietário, o despejo das famílias indígenas aconteceu, designado pelo desembargador Raimundo José de Barros.

No quadro 3 também identificamos que as invasões possessórias, a exploração ilegal de recursos naturais e os danos diversos ao patrimônio decaíram no ano de 2015 , porém, aumentaram nos anos de 2016 a 2019 , especialmente nesse último ano, mais de $130 \%$, comparado com o ano anterior.

Esse crescimento exponencial no ano de 2019, segundo Paloschi (2020), dá-se, em grande medida, porque o governo Bolsonaro implementa uma política nefasta no tocante aos povos indígenas e à natureza, incentivando as invasões de terras indígenas e apoiando explicitamente os setores que se beneficiam com os crimes que praticam nos territórios tradicionais dos povos originários.

Entre os tipos de danos e ataques aos territórios indígenas, de acordo com o Cimi $(2015 ; 2016 ; 2017 ; 2018 ; 2019 b ; 2020)$, estão: o arrendamento e loteamento de terras indígenas; a destruição de casas, aldeias e pontes; as invasões; a exploração ilegal de recursos naturais atividades pesqueiras de grande e médio porte, caça e comercialização de animais silvestres, exploração madeireira, etc. -; o desmatamento; as queimadas; os incêndios; a garimpagem (ouro e diamante); a contaminação de rios; a contaminação por agrotóxicos e metais pesados e as ações criminosas que incluem a abertura de rotas para o tráfico de drogas.

As fotografias 7 e 8 ilustram essas formas de danos e ataques aos territórios indígenas. 
Fotografias 7 e 8 - Desmatamento na Terra Indígena Karipuna em Rondônia.

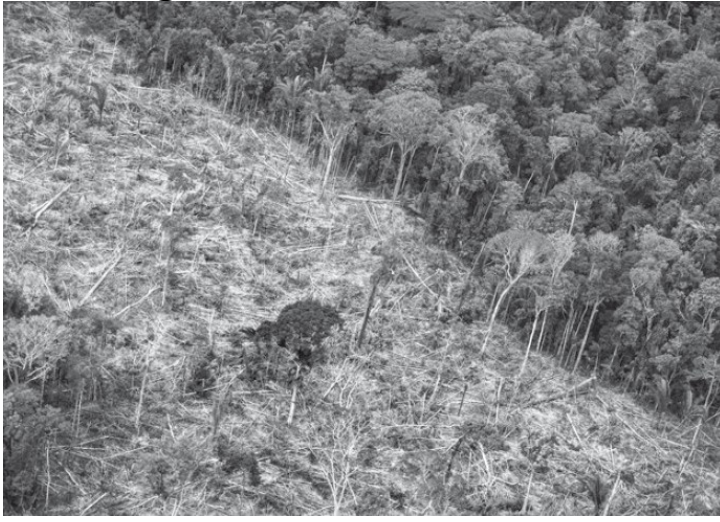

Fonte: Christian Braga/Greenpeace/Cimi (CIMI, 2019b, p. 57).

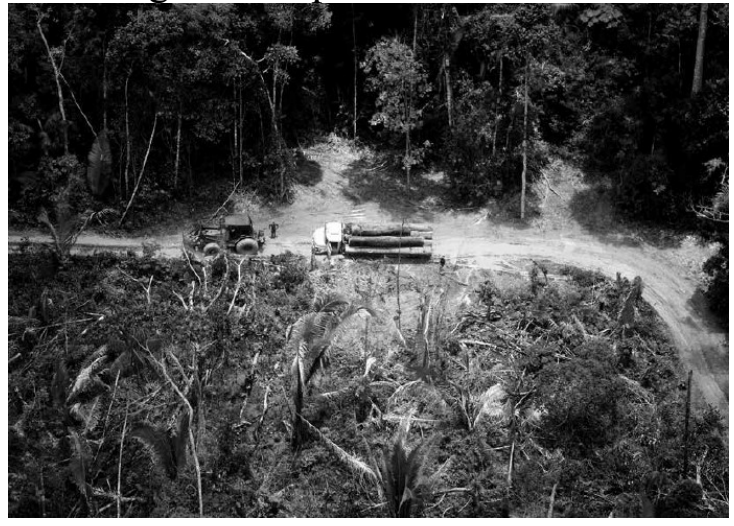

Fonte: Chico Batata/Greenpeace (CIMI, 2020, p. 80).

No caso do povo Puruborá, houve denúncia de desmatamento por parte da comunidade - conforme exposto no quadro 5 - e de extrações ilegais de madeira e de castanha - indicado no quadro 6.

Quadro 5 - Violência contra o patrimônio - desmatamento na terra indígena Puruborá (2014).

TERRA INDÍGENA: PUROBORÁ

POVO(S): PURUBORÁ

TIPO DE DANO/CONFLITO: Desmatamento

DESCRIÇÃO: Fazendeiros têm desmatado grandes áreas, derrubando árvores frutíferas que são importante fonte de alimento do povo indígena Puruborá. O desmatamento, que era feito com motosserra, agora se dá pelo envenenamento das raízes das árvores que, após o apodrecimento, são derrubadas e utilizadas na construção de casas para os fazendeiros da região.

Com informações de: Lideranças indígenas

Fonte: Cimi (2015, p. 54, grifos do autor).

Quadro 6 - Violência contra o patrimônio - extração ilegal de madeira e de castanha territórios Puruborá e Kujubim (2018).

POVOS: KUJUBIM e PURUBORÁ

TIPO DE DANO/CONFLITO: Extração ilegal de madeira; extração ilegal de castanha

DESCRIÇÃO: Devido à morosidade no processo de demarcação, paralisado desde 2015, os territórios indígenas Kujubim e Puroborá são constantemente invadidos por pecuaristas, produtores de soja, madeireiros e invasores que fazem a extração ilegal da castanha.

Com informaç̃̃es de: Comunidades indígenas

Fonte: Cimi (2019b, p. 67, grifos do autor).

Fica evidente então que, enquanto esperam o seu território tradicional ser demarcado oficialmente, os e as Puruborá o veem ser degradado e as árvores (frutíferas ou não) existentes dentro da terra indígena - entre elas as castanheiras - serem derrubadas, restando-lhes tão somente denunciar esses crimes ambientais e exigir atuação dos órgãos competentes. Salientamos que não existem apenas essas duas denúncias do povo Puruborá em relação à violência contra seu patrimônio, mas outras tantas são registradas cotidianamente. 


\section{Violências provocadas por omissão do poder público}

O quadro 7 a seguir indica as violências provocadas por omissão do poder público, entre elas, a desassistência na área da educação escolar indígena e na área da saúde. Entre os números mais expressivos, estão os referentes aos suicídios e à mortalidade infantil.

A partir do quadro 7, percebemos que o ano de 2019 bateu o recorde de todos os tipos de violência por omissão do poder público, referente aos dados de 2014 a 2019, com exceção de suicídio, que em 2014 teve o maior número de casos. Destacamos também que os números de 2019 são expressivamente maiores do que os dos anos anteriores.

Quadro 7 - Violência por omissão do poder público - Dados de 2014 a 2019.

\begin{tabular}{|lcccccc|}
\hline \multicolumn{1}{|c}{ Tipos de violência / ano } & $\mathbf{2 0 1 4}$ & $\mathbf{2 0 1 5}$ & $\mathbf{2 0 1 6}$ & $\mathbf{2 0 1 7}$ & $\mathbf{2 0 1 8}$ & $\mathbf{2 0 1 9}$ \\
\hline Desassistência geral & 40 & 36 & 42 & 42 & 35 & 65 \\
\hline $\begin{array}{l}\text { Desassistência na área da educação escolar } \\
\text { indígena }\end{array}$ & 53 & 41 & 38 & 41 & 41 & 66 \\
\hline Desassistência na área da saúde & 79 & 52 & 42 & 42 & 44 & 85 \\
\hline $\begin{array}{l}\text { Disseminação de bebida alcoólica e outras } \\
\text { drogas }\end{array}$ & 13 & 5 & 3 & 10 & 11 & 20 \\
\hline Morte por desassistência à saúde & 21 & 3 & 3 & 8 & 11 & 31 \\
\hline Suicídio & 135 & 87 & 106 & 128 & 101 & 133 \\
\hline Mortalidade na infância & 785 & 599 & 735 & 702 & 591 & 825 \\
\hline Total de casos & 1.12 & 823 & 969 & 973 & 834 & 1.22 \\
& 6 & & & & & 5 \\
\hline
\end{tabular}

Fonte: Construído pela pesquisadora apoiado nos relatórios de violência contra os povos indígenas no Brasil - dados de 2014 a 2019 (CIMI, 2015; 2016; 2017; 2018; 2019b; 2020).

Entre os danos e ataques causados aos povos indígenas do Brasil relativos à desassistência geral estão o desleixo com cadáver, a falta de registro civil de crianças, a falta de reconhecimento do território tradicional e a situação de extrema vulnerabilidade - agravada pela falta de políticas públicas (CIMI, 2019b).

Entre os danos e ataques referentes à desassistência na área da educação escolar indígena estão as dificuldades no reconhecimento oficial das escolas, na criação de novas escolas ou na ampliação de vagas; as salas de aula improvisadas; as péssimas condições de saneamento básico e de infraestrutura - prédios mal conservados, paredes apodrecidas, telhas e janelas quebradas, fiação exposta, cadeiras deterioradas, banheiros danificados, salas sem ventilação etc.; a falta de cadeiras e mesas; a ausência de material didático específico; a descontinuidade na formação de professores e professoras indígenas; a falta de acompanhamento pedagógico dos professores e das professoras; a ausência de implantação do ensino fundamental completo e do ensino médio e o atraso no pagamento dos docentes em diversas regiões (CIMI, 2019b). 
Espaço Ameríndio

Fotografia 9 - Escola indígena com ausência de prédio adequado, mesas e cadeiras (2017).

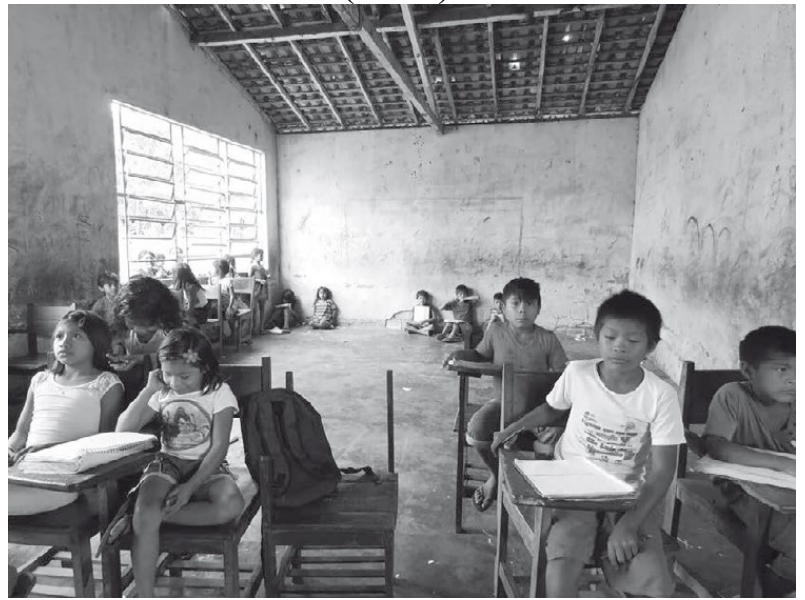

Fonte: Arão Marise (CIMI, 2018, p. 138).

A fotografia 9, testemunha que - apesar dos avanços significativos em relação à educação escolar indígena, entre eles, as legislações elaboradas (FERREIRA, 2007) -, essa educação ainda sofre as consequências da omissão do poder público, possuindo muitos desafios, entre eles, o da infraestrutura das escolas indígenas e da falta de cadeiras e mesas.

Dessa forma, de acordo com Abbonizio (2013, p. 52-53):

Se as novas escolas indígenas fossem avaliadas em termos de estrutura física, recursos materiais, alimentação escolar, aparelhos esportivos, bibliotecas, laboratórios, acessibilidade e, sobretudo, acompanhamento técnico-pedagógico das equipes das secretarias de educação, provavelmente comporiam um quadro das escolas brasileiras de maior precariedade, como se a prerrogativa de ser escola situada em terra indígena justificasse seu isolamento e restrição a outros direitos.

No caso do povo Puruborá, em 2018, houve duas denúncias. A primeira tratou-se da falta de transporte para estudante Puruborá residente na Terra Indígena do povo Migueleno frequentar a escola do povo Migueleno em São Francisco do Guaporé; a segunda referia-se à falta do ensino fundamental II e à necessidade de ampliação da escola indígena Ywará Puruborá, situada na aldeia Aperoi - território Puruborá (Quadro 8).

Quadro 8 - Violência por omissão do poder público - falta do ensino fundamental II e necessidade de ampliação da escola do povo Puruborá (2018).

VÍTIMA: Estudantes

POVO: PURUBORA

TERRA: PUROBORÁ

MUNICÍPIO: SERINGUEIRAS

LOCAL DA OCORRÊNCIA: Aldeia Aperoy 
DESCRIÇÃO: A aldeia possui uma escola de ensino fundamental, mas somente para os primeiros cinco anos, e com apenas uma sala de aula. A comunidade solicitou urgência na ampliação da escola para que o ciclo do ensino fundamental até a $9^{\text {a }}$ série seja completo, e mais salas de aula. Denúncias foram feitas ao MPF e à Seduc ${ }^{16}$.

MEIO EMPREGADO: Falta de escola

Com informações de: Cimi Regional Rondônia

Fonte: Cimi (2019b, p. 114, grifos do autor).

No ano de 2019, houve uma denúncia reforçando a ausência do ensino fundamental II e a necessidade de ampliação da escola indígena Ywará Puruborá (Quadro 9), já que os estudantes que concluem a primeira etapa do ensino fundamental necessitam continuar a escolarização fora da aldeia ou até abandoná-la, além de que a escola do povo Puruborá não possui estrutura adequada, já que é pequena para atender a demanda da comunidade (Fotografias 10 a 12).

Quadro 9 - Violência por omissão do poder público - falta de escola e de professores indígenas no povo Puruborá (2019).

VÍTIMA: Estudantes e professores

POVO: PURUBORÁ

TERRA INDÍGENA: PUROBORÁ

MUNICÍPIO: SERINGUEIRAS

LOCAL DA OCORRÊNCIA: Aldeia Aperoy

DESCRIÇÃO: Lideranças relatam que há, na aldeia, a oferta de ensino fundamental de Primeiro Ciclo - do 10 ao 50 ano - e do ensino médio, com ensino tecnológico. Porém, não está em andamento o segundo ciclo do ensino fundamental e, neste caso, os jovens e adolescentes que pretendem continuar os estudos terão de se deslocar para a cidade de Seringueira ou abandonar os estudos. Esse fato acabou sendo denunciado ao MPF e à secretaria de educação para uma ação imediata no sentido de viabilizar o ensino completo, além da construção de uma escola adequada e digna, pois, atualmente, só há uma sala de estudo em estado precário.

MEIO EMPREGADO: Falta de escola e professores indígenas

Com informações de: Lideranças; Cimi Regional Rondônia

Fonte: Cimi (2020, p. 167, grifos do autor).

Fotografias 10 a 12 - Escola indígena Ywará Puruborá (2018).
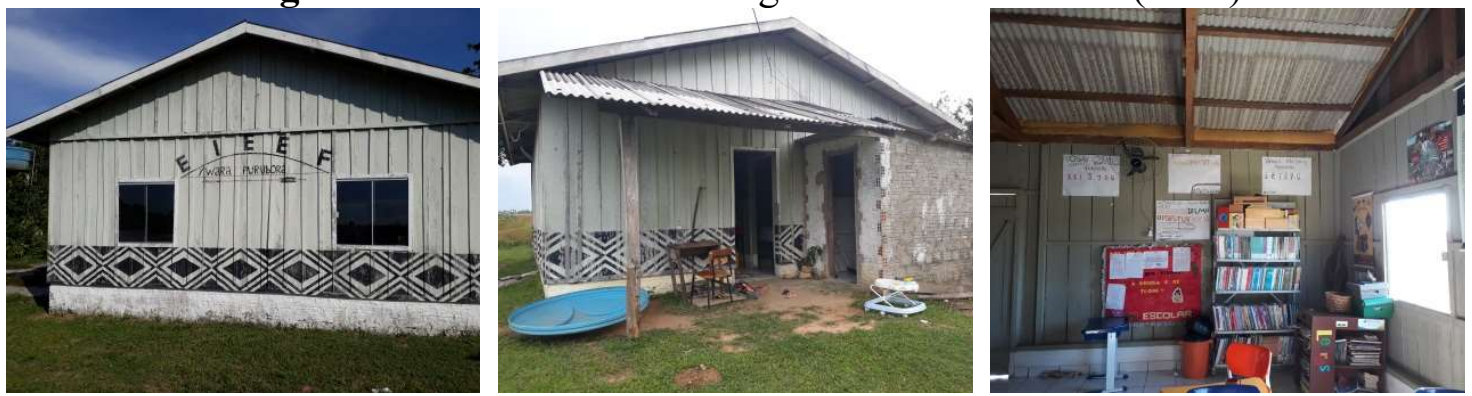

Fonte: Acervo pessoal da primeira autora.

A não ampliação do atendimento no Ensino Fundamental II na escola indígena Ywará Puruborá ocasionou um número reduzido de estudantes matriculados. Com isso, no início de 2020, a instituição foi fechada sem a consulta do povo da aldeia Aperoi, que somente foi avisado em uma

\footnotetext{
${ }^{16}$ Secretaria de Estado da Educação.

RAMOS, Anatália Daiane de Oliveira; ZIBETTI, Marli Lúcia Tonatto; CAETANO, Edson. Violências e resistências: povos indígenas do brasil e o povo Puruborá da aldeia Aperoi - RO. Espaço Ameríndio, Porto Alegre, v. 15, n. 2, p. 206-238, mai./ago. 2021.
} 
reunião convocada pela Coordenadoria Regional de Educação (CRE) do Estado de Rondônia.

Também são significativos os números relacionados à desassistência na área da saúde. Entre os dados desse tipo de desassistência estão a negligência no atendimento e a omissão no socorro; o descuido no transporte de pacientes e na distribuição de remédios; o descaso com medidas de infraestrutura sanitária; a água contaminada; a falta de acesso à água e os desvios de remédios para comércio ilegal dentro de aldeias (CIMI, 2019b).

Nesse sentido, o Cimi (2015, p. 118) alega que:

No estado do Pará, onde foi registrado o maior número de casos, indígenas de vários povos sofrem com a precariedade das Casas de Apoio à Saúde Indígena (Casai). Em Altamira, a Casai encontrava-se com sistemas elétrico e hidráulico quebrados, banheiros sem estrutura e falta de saneamento. Com capacidade para 70 pessoas, a casa abrigava mais de 300 indígenas. Situação semelhante foi observada no município de Oriximiná, onde a Casai encontrava-se superlotada, com indígenas sendo atendidos debaixo de lonas e com alojamentos improvisados, feitos pelos próprios índios.

Além dessas queixas, outras relacionadas à falta de enfermarias, medicamentos, agente indígena de saúde ou agente indígena de saneamento, radiofonia e manutenção nos veículos destinados a transportar indígenas com problemas de saúde são frequentes no que se refere à (des)assistência da saúde indígena.

Entre os casos de desassistência na área da saúde do ano de 2014, encontra-se aquele denunciado pela comunidade Puruborá, tal qual destacado no quadro 10 a seguir.

Quadro 10 - Violência por omissão do poder público - falta de estrutura na Casai (Puruborá-2014).

\section{4}

VÍTIMA: Comunidade

POVOS: PURUBORÁ

TERRA INDÍGENA: PURUBORÁ

MUNICÍPIO: SERINGUEIRAS

DESCRIÇÃO: As comunidades denunciam que a Casai de Jarú está sucateada. De acordo com os relatos, há falta de medicamentos, enfermarias e a infraestrutura é precária. O mais grave é a falta de saneamento básico. Além disso, faltam itens básicos como colchões, roupa de cama, ventiladores. As lideranças estão reivindicando a construção de uma nova casa de atendimento. Relatam também que houve um aumento grande de casos de hepatite e de tuberculose e outras enfermidades.

MEIO EMPREGADO: Falta de estrutura na Casai

FONTE: Cimi Regional Rondônia

$$
\text { Fonte: Cimi (2015, p. 128, grifos do autor). }
$$

O quadro 7 revela ainda que foram registrados 77 casos de morte por desassistência à saúde nos anos de 2014 a 2019. Contudo, julgamos que a quantidade de vítimas desse tipo de violência pode ser mais 
significativa, uma vez que o relatório de 2014 cita os dados da quantidade de vítimas dentro dos casos: 82 pessoas foram vítimas nos 21 casos registrados de morte por desassistência à saúde (CIMI, 2015).

Entre as mortes por desassistência à saúde estão aquelas causadas por doenças respiratórias - como gripes que evoluem para pneumonia e tuberculose; doenças infecciosas e parasitárias; problemas no aparelho circulatório e por câncer (CIMI, 2019b). Entre as vítimas dos 11 casos registrados em 2018 está Dona Zuila Jaboti - povo indígena Jabuti -, da Terra Indígena Rio Guaporé, no município de Guajará-Mirim, Estado de Rondônia.

O Cimi (2019b, p. 126) registra que ela foi vítima da omissão e negligência do poder público: "A demora na entrega do laudo de exame ginecológico por parte da Casai de Guajará-Mirim dificultou o tratamento do câncer do colo de útero. O exame, feito no ano de 2014 , só foi entregue em 2016. Por ter iniciado o tratamento tardiamente, a vítima veio a óbito".

\section{Violência contra povos indígenas isolados e de pouco contato}

Além do alto número de violência contra o patrimônio, contra a pessoa e provocada por omissão do poder público já analisados, o relatório de violência contra os povos indígenas no Brasil, dados de 2014 a 2019, produzidos pelo Cimi, também indica a violência contra povos indígenas isolados e de pouco contato.

Maracci (2012, p. 609) narra que a realidade dos povos isolados e de pouco contato é desesperadora, uma vez que eles "[...] são os mais vulneráveis pois não possuem nenhum instrumento de luta contra o avanço do grande capital".

Por esse ângulo, no relatório de violência contra os povos indígenas - dados de 2014 -, o Cimi (2015) denuncia que nas últimas décadas os povos indígenas isolados têm sofrido o crime de genocídio na Amazônia e são vítimas do avanço do agronegócio, da exploração petrolífera e madeireira, das obras de infraestrutura, das construções de estradas, linhas férreas, usinas hidrelétricas, da exploração de minerais sobre suas terras, do desmatamento, das queimadas e invasões das terras indígenas e unidades de conversação.

O Cimi (2015, p. 157, grifo do autor) explica que:

Os povos em situação de isolamento voluntário ou livres, são as maiores vítimas do "desenvolvimento" da Amazônia, que continua a ser feito através de um violento e silencioso processo de expropriação de terras dos povos tradicionais. Ironicamente, são justamente esses povos que sempre protegeram a floresta, já que dependem totalmente dela para a sua sobrevivência.

De acordo com o Cimi (2020), o sistema de proteção oficial que existe para os povos indígenas isolados e de pouco contato é insuficiente e está sendo inviabilizado, uma vez que sofre com a escassez de recursos 
humanos e financeiros, em decorrência da antipolítica indigenista do novo governo federal.

Diante do exposto, percebemos que, atualmente, no Brasil predomina uma política de desconstrução de direitos e deterioração da vida e dos recursos existentes dentro dos territórios indígenas, comprovada num número elevado de violações e violências contra os povos indígenas (CIMI, 2017).

\section{Considerações finais}

A temática indígena, independente do assunto tratado (escola, saúde institucionalizada, território, cultura, produção da existência, etc.), é polêmica e permeada de preconceitos e representações equivocadas acerca dos povos indígenas, contribuindo com a produção, perpetuação e reprodução de violências e violações de direitos desses povos.

Os dados discutidos no presente texto são dados do século XXI anos de 2014 a 2019 -, ou seja, contemporâneos. Entretanto, as violências e violações dos direitos dos povos indígenas de nosso país são antigas - desde a invasão do Brasil. Apesar das especificidades de cada povo indígena, as violências, as violações de direitos e as resistências dos indígenas os caracterizam como semelhantes.

Também é atual e, concomitantemente antiga, as resistências dos povos indígenas brasileiros. Essas resistências são fruto de interesses, lógica e modos de viver e saber diferentes e antagônicos entre os povos indígenas e a sociedade capitalista.

Se por um lado, na sociedade capitalista, a lógica que organiza seu funcionamento é a da exploração (recursos naturais, força de trabalho, etc.), grilagem e invasão das terras indígenas, expulsão dos indígenas, crescimento a qualquer custo - inclusive à exaustão da natureza -, pelo consumo sem controle, pela concentração de riquezas etc.; por outro lado, os povos indígenas lutam pela preservação do seu território, pela Pacha Mama (Mãe Terra), pela proibição do desmatamento, das derrubadas, da grilagem e invasão de terras, pela conservação da natureza e dos outros seres, pela manutenção das suas culturas, etc.

Os interesses antagônicos existentes entre os povos indígenas e a sociedade capitalista têm se materializado em invasões, explorações ilegais de recursos naturais, ameaças de morte, tentativas de assassinato, perseguição, assassinatos e outras violências contra os mesmos, além das violações dos direitos conquistados tão arduamente.

As violências ocorrem contra a pessoa, o patrimônio, os povos indígenas isolados e de pouco contato e por omissão do poder público. Entretanto, isso não acontece sem a resistência dos povos indígenas, que ocorre de forma explícita, direta ou aberta por meio de mobilizações em Brasília e outras localidades do país, fechamento de rodovias etc. ou de forma explícita, indireta ou dissimulada por meio do "resgate" dos saberes tradicionais, de práticas culturais, costumeiras e identitárias, da produção fundamentada em sementes crioulas, etc.

Inclusive, os povos indígenas brasileiros têm se articulado em organizações - associações e entidades de luta -, que se constituem nas 
aldeias e envolvem todas as aldeias de uma etnia e/ou de maneira regional, nacional e internacional. Essas articulações possibilitam as mobilizações e participações em eventos em torno da luta pelo território, pela educação escolar indígena, pela saúde indígena e pelos outros direitos formalmente conquistados.

Entidades como o Cimi e o Conselho de Missão entre Povos Indígenas (Comin) denunciam as violências e violações dos direitos indígenas de nosso país por meio de várias ações, entre elas, a publicação dos relatórios de violência contra os povos indígenas do Brasil de autoria do Cimi.

Os dados publicados pelo Cimi são preocupantes e alarmantes, inclusive, porque demonstram que pode ainda ser superior o número de vítimas de violências e violações de direitos, já que, por exemplo, no caso de violência contra a pessoa e por omissão do poder público, alguns casos registrados têm mais de uma pessoa envolvida e em alguns relatórios, a entidade só traz a quantidade de casos e não indica o número de vítimas em cada um deles.

Evidenciamos que o ano de 2019 se destacou devido ao grande número de violências e violações de direitos dos povos indígenas. Esse aumento dos casos de violências e violações de direitos identificados nesse ano é denunciado como fruto da política do governo Bolsonaro, caracterizado por Oliveira e Buzatto (2020), como uma pessoa com o perfil violento, autoritário, desrespeitoso e preconceituoso, e indicado como destruidor de políticas sociais e de reparação.

Indicamos a importância das pesquisas realizadas por entidades ou grupos criados para apoiar os povos indígenas como o Cimi e o Comin, que, como já afirmamos, recolhem, sistematizam e denunciam as violências e violações dos direitos indígenas brasileiros. Porém, apontamos a necessidade do fomento e da realização de pesquisas científicas que tenham como finalidade a investigação das violências e violações dos direitos indígenas do Brasil para dialogar com essas pesquisas realizadas pelas entidades mencionadas ou outras produzidas por grupos criados para apoiar os povos indígenas.

Como identificamos no decorrer do texto, o Povo Puruborá da aldeia Aperoi também é alvo de violências e violações: contra a pessoa, contra o patrimônio e por omissão do poder público. Mas não sem resistência, característica peculiar dos povos indígenas do Brasil. A ausência do reconhecimento e da formalização da demarcação feita por Marechal Rondon, por exemplo, é uma das violações de direito do povo Puruborá.

A colonização e o desenvolvimento do Estado de Rondônia materializaram várias violações de direitos e violências contra vários povos indígenas do Estado, entre eles, o povo Puruborá. A extração da borracha, por exemplo, explorou a força de trabalho dos Puruborá; reduziu o número de indígenas; forçou os Puruborá a não utilizarem sua língua e cultura e a se submeter a novos padrões - cultura, vestimenta, modo de organização etc.; impôs a mestiçagem por meio de práticas como casamentos forçados; introduziu doenças como sarampo; permitiu 
o furto de seu território tradicional que ainda não tinha sido demarcado oficialmente; negou o reconhecimento da identidade indígena, etc.

As três expulsões do território tradicional e o atual fato da aldeia Aperoi não estar localizada em território demarcado evidenciam a violação de um direito constitucional e a não concretização desse direito causam vários tipos de violências contra o povo Puruborá: ameaças constantes, desmatamento no território tradicional - que atualmente está quase inteiramente sob propriedade e posse de fazendeiros -, desassistência na educação escolar indígena - inclusive com o fechamento da escola -, exploração da força de trabalho indígena, já que muitos indígenas precisam trabalhar e, devido à necessidade, se submetem a diversos tipos de trabalhos, inclusive aqueles sem garantias trabalhistas.

A resistência do povo Puruborá frente às violências e violações de direitos acontece cotidianamente. Fazem e participam de mobilizações locais - na aldeia, no município em que residem, mas também foram dele (nacional e internacionalmente) anunciando e denunciando violências e violações, lutando pelos seus direitos.

Entre as mobilizações realizadas pelo povo Puruborá da aldeia Aperoi estão aquelas a favor da demarcação oficial de seu território tradicional, uma vez que a terra para o povo Puruborá é mais que um espaço para (re)produzir a vida. A terra é espaço de (re)produzir a identidade, a Língua Puruborá, a afetividade, a solidariedade, a reciprocidade, a unidade grupal, a cultura, a autoestima... enfim, a existência como um todo. Aliás, é por isso que o povo Puruborá denuncia os crimes ambientais ocorridos em seu território cometidos por terceiros.

Por fim, considerando que o Estado também cria e sustenta as violências e violações contra os povos indígenas de nosso país, parece existir uma política de desconstrução de direitos e deterioração da vida e dos recursos das terras indígenas e a superação desta política é responsabilidade de todos aqueles e aquelas que não compactuam com a agressão ou o extermínio da vida humana. 
Espaço Ameríndio

\section{Referências bibliográficas}

ABBONIZIO, Aline Cristina de Oliveira. Educação escolar indígena como inovação educacional: a escola e as aspirações de futuro das comunidades. 2013. 192f. Tese (Doutorado em Educação) - Faculdade de Educação, USP, São Paulo, SP, 2013.

AMORIM, Siloé Soares de. Os Kalankó, Karuazu, Kaoipanká e Katokinn: resistência e ressurgência indígena no Alto Sertão alagoano. 2010. 431f. Tese (Doutorado em Antropologia Social) - PPGAS, UFRGS, Porto Alegre, RS, 2010.

ANDRÉ, Marli Eliza Dalmazo Afonso de. Etnografia da prática escolar. 11 ed. Campinas, SP: Papirus, 2004.

ANDRÉ, Marli Eliza Dalmazo Afonso de. O repensar da didática a partir do estudo da dominação e resistência no cotidiano escolar. R. Fac. Educ., São Paulo, v. 14, n. 1, p. 35 41, jan./jun. 1988.

BARBOZA, José Joaci. Puruborá: narrativas de um povo ressurgido na Amazônia. In: XI ENCONTRO NACIONAL DE HISTÓRIA ORAL, 2012, Rio de Janeiro. Anais eletrônicos... [...] Rio de Janeiro: Instituto de Filosofia e Ciências Sociais/Instituto de História da Universidade Federal do Rio de Janeiro, 2012. Disponível em: http://www.encontro2012.historiaoral.org.br/resources/anais/3/1339991713 ARQUIVO PuruboraNarrativasdeumPovoRessurgidonaAmazonia.pdf. Acesso em: 08 ago. 2013.

BRANDÃO, Carlos Rodrigues. A pesquisa participante e a participação da pesquisa: um olhar entre tempos e espaços a partir da América Latina. In: BRANDÃO, Carlos Rodrigues; STRECK, Danilo Romeu (Orgs.). Pesquisa participante: o saber da partilha. Aparecida, SP: Ideias \& Letras, 2006. p. 21-54.

BRASIL. Câmara dos deputados. PEC 187/2016. Acrescenta o $\S 8^{\circ}$ ao art. 231 da Constituição Federal de 1988, a fím de permitir às comunidades indígenas praticar atividades agropecuárias e florestais em suas terras, bem como, comercializar aquilo que foi produzido e gerenciar sua renda. Disponível em: https://www.camara.leg.br/proposicoesWeb/fichadetramitacao?idProposicao=2077621.

Acesso em: 21 set. 2019.

BRASIL. Câmara dos deputados. PEC 343/2017. Dá nova redação ao artigo 231 da Constituição Federal para tratar da implantação de parceria agrícola e pecuária entre a Funai - Fundação Nacional do Índio, e terceiros. Disponível em: https://www.camara.leg.br/proposicoesWeb/fichadetramitacao?idProposicao=2143792. Acesso em: 21 set. 2019.

BRASIL. Portaria $\mathrm{n}^{\circ} 1.061$, de 11 de setembro de 2014. Diário Oficial da União, $\mathrm{n}^{\circ} 176$, 12 set. $2014 . \quad$ Disponível em http://pesquisa.in.gov.br/imprensa/jsp/visualiza/index.jsp?jornal=2\&pagina $=48 \&$ data $=1$ 2/09/2014. Acesso em: 07 out. 2014. 
Espaço Ameríndio

BRIGHENTI, Clóvis Antônio. O "desenvolvimento" versus os povos indígenas. In: CONSELHO INDIGENISTA MISSIONÁRIO (CIMI). Relatório Violência contra os povos indígenas no Brasil - Dados de 2014. Brasília, DF: CIMI, 2015. p. 20-25.

CATHEU, Gil de. Puruborá: mais um povo ressurgido em Rondônia. Conselho Indigenista Missionário de Rondônia (Cimi-RO). 20 fev. 2002. Disponível em: http://pib.socioambiental.org/en/noticias?id=4615. Acesso em: 16 mar. 2014.

CIMI-ANE (Articulação Nacional de Educação). Memória e Resistência: a sabedoria dos povos indígenas. 2004.

CONSELHO INDIGENISTA MISSIONÁRIO (CIMI). Abertura de terras indígenas para exploração será retirada de PEC 187, após mobilização. 22 ago. 2019a. Disponível em: https://cimi.org.br/2019/08/abertura-de-terras-indigenas-paraexploracao-sera-retirada-de-pec-187-apos-mobilizacao/. Acesso em: 07 set. 2019. Não paginado.

CONSELHO INDIGENISTA MISSIONÁRIO (CIMI). Por uma educação descolonial e libertadora: manifesto sobre a educação escolar indígena no Brasil. Brasília, DF: CIMI, 2014.

CONSELHO INDIGENISTA MISSIONÁRIO (CIMI). Relatório Violência contra os povos indígenas no Brasil - Dados de 2014. Brasília, DF: CIMI, 2015.

CONSELHO INDIGENISTA MISSIONÁRIO (CIMI). Relatório Violência contra os povos indígenas no Brasil - Dados de 2015. Brasília, DF: CIMI, 2016.

CONSELHO INDIGENISTA MISSIONÁRIO (CIMI). Relatório Violência contra os povos indígenas no Brasil - Dados de 2016. Brasília, DF: CIMI, 2017.

CONSELHO INDIGENISTA MISSIONÁRIO (CIMI). Relatório Violência contra os povos indígenas no Brasil - Dados de 2017. Brasília, DF: CIMI, 2018.

CONSELHO INDIGENISTA MISSIONÁRIO (CIMI). Relatório Violência contra os povos indígenas no Brasil - Dados de 2018. Brasília, DF: CIMI, $2019 \mathrm{~b}$.

CONSELHO INDIGENISTA MISSIONÁRIO (CIMI). Relatório Violência contra os povos indígenas no Brasil - Dados de 2019. Brasília, DF: CIMI, 2020.

CONSELHO INDIGENISTA MISSIONÁRIO DE RONDÔNIA (Cimi-RO). Puruborá. In: CONSELHO INDIGENISTA MISSIONÁRIO DE RONDÔNIA (Cimi-RO). Panewa Especial, Porto Velho, jul. 2002. p. 59-60.

CONSELHO NACIONAL DE SAÚDE (CNS). Resolução 466, de 12 de dezembro de 2012. Disponível em: http://conselho.saude.gov.br/resolucoes/2012/Reso466.pdf. Acesso em: 9 dez. 2013.

CONSELHO NACIONAL DE SAÚDE (CNS). Resolução 510, de 07 de abril de 2016. Disponível em: http://conselho.saude.gov.br/resolucoes/2016/Reso510.pdf. Acesso em: 5 set. 2016. 
FERREIRA, Geraldo Veloso. Educação Escolar Indígena: As práticas culturais indígenas na ação pedagógica da Escola Estadual Indígena São Miguel - Iauaretê (AM). 2007. 207f. Dissertação (Mestrado em Educação) - PUC-SP, São Paulo, SP 2007.

FONSECA FILHO, Olympio. Afinidades parasitologicas e clinicas: entre o tokelau da Asia e da Oceania e o chimbêrê dos indigenas de Matto-Grosso. In: ROQUETTE-PINTO, Edgar. Rondônia. 5 ed. São Paulo: Ed. Nacional, 1950. p. 353-363.

FRIGOTTO, Gaudêncio. O enfoque da dialética materialista histórica na pesquisa educacional. In: FAZENDA, Ivani (Org.). Metodologia da pesquisa educacional. São Paulo: Cortez, 1989. p. 69-90.

GALUCIO, Ana Vilacy. Puruborá: notas etnográficas e lingüísticas recentes. Boletim do Museu Paraense Emílio Goeldi, Belém, v. 1, n. 2, p. 159-192, maio/ago. 2005. Disponível em: http://repositorio.museugoeldi.br/bitstream/mgoeldi/700/1/B\%20MPEG $\% 20 \mathrm{C} \% 20 \mathrm{Hum} \% 201 \% 282 \% 29 \% 20200$ 5\%20GALUCIO.PDF. Acesso em: 21 ago. 2017.

KOCH-GRÜNBERG, Theodor. Wörterlisten « tupý », maué und purúborá. Journal de la Société des Américanistes, tome 24, n 1, p. 31-50, 1932. Disponível em: http://etnolinguistica.wdfiles.com/local--files/artigo\%3Akoch-grunberg-1932wortlisten/koch-grunberg_1932_wortlisten_persee.pdf. Acesso em: 25 ago. 2017.

KRÄUTLER, Erwin. "Aquele que usou de misericórdia... Vai e faze tu o mesmo!” In: CONSELHO INDIGENISTA MISSIONÁRIO (CIMI). Relatório Violência contra os povos indígenas no Brasil - Dados de 2014. Brasília, DF: CIMI, 2015. p. 10-11.

LABORATÓRIO DE GEOMÁTICA E ESTATÍSTICA (LABGET) DA FUNDAÇÃO UNIVERSIDADE FEDERAL DE RONDÔNIA (UNIR). Mapa de localização da aldeia Aperoi. Organização Angela Guidelli. Coordenação Alex Mota dos Santos. JiParaná, Rondônia: UNIR, 2013.

MARACCI, Marilda Teles. Povos indígenas. In: CALDART, Roseli Salete; PEREIRA, Isabel Brasil; ALENTEJANO, Paulo; FRIGOTTO, Gaudêncio (Orgs.). Dicionário da Educação do Campo. Rio de Janeiro, São Paulo: Escola Politécnica de Saúde Joaquim Venâncio, Expressão Popular, 2012. p. 602-614.

MARIÁTEGUI, José Carlos. Por um socialismo indo-americano. Tradução Luiz Sérgio Henriques. Rio de Janeiro: Editora UFRJ, 2005.

MARIÁTEGUI, José Carlos. Sete ensaios de interpretação da realidade peruana. Tradução Felipe José Lindoso. 2 ed. São Paulo: Expressão Popular; Clacso, 2010.

MENEZES, Tarsila dos Reis. “O passado, o presente e o futuro nas plantas Puruborá (Rondônia)". 2016. 237f. Dissertação (Mestrado em Antropologia Social) - PPGAS, UFSCar, São Carlos, SP, 2016.

MONTANHA, Gisele de Oliveira; BARBOZA, José Joaci; OLIVEIRA, Anatália Daiane de. Puruborá: mitos de um povo indígena ressurgido da Amazônia. Tellus, Campo 
Espaço Ameríndio

Grande, ano 14, n. 27, p. 151-174, jul./dez. 2014. Disponível em: http://www.tellus.ucdb.br/index.php/tellus/article/view/326/333. Acesso em: 29 ago. 2017.

NIMUENDAJÚ, Curt. Mapa etno-histórico do Brasil e regiões adjacentes. Rio de Janeiro: IBGE/Fundação Nacional Pró-Memória, 1981. Disponível em: http://etnolinguistica.wdfiles.com/local--files/biblio\%3Animuendaju-1981mapa/nimuendaju 1981 mapa.jpg. Acesso em: 12 ago. 2017.

OLIVEIRA, Anatália Daiane de. Escolarização indígena e identidade Puruborá: contribuições da escola para um povo ressurgido/resistente na Amazônia. 2015. 232f. Dissertação (Mestrado em Psicologia) - PPGPSI, UNIR, Porto Velho, RO, 2015.

OLIVEIRA, Anatália Daiane de; BRITO, Claudineia Gomes; BARBOZA, José Joaci. Puruborá: indígenas ressurgidos e a construção da identidade. P@rtes, São Paulo, jun. 2014. Disponível em: Acesso em: http://www.partes.com.br/2014/06/23/puruboraindigenas-ressurgidos-e-a-construcao-da-identidade/. Acesso em 24 jun. 2014.

OLIVEIRA, Anatália Daiane de; BRITO, Claudineia Gomes; BIAZATTI, Suzana das Candeias; BARBOZA, José Joaci. Mulheres Puruborá, índias e seringueiras: uma história de Gênero. In: V SEMINÁRIO DE EDUCAÇÃO, 2012, Rolim de Moura. Anais..., Rolim de Moura, RO: Fundação Universidade Federal de Rondônia, 2012.

OLIVEIRA, Anatália Daiane de; BRITO, Claudineia Gomes; BIAZATTI, Suzana das Candeias. Percepção de território para o povo Puruborá: Alguns apontamentos. In: XXX SEMANA DE GEOGRAFIA/I ENCONTRO INTERNACIONAL DE GEOGRAFIA, 2012, Porto Velho. Anais eletrônicos..., Porto Velho: Fundação Universidade Federal de Rondônia, $2012 . \quad$ Disponível em: https://www.dropbox.com/s/v54eh273azhx5id/artigo\%20percepa\%C3\%A7\%C3\%A3o. pdf?m. Acesso em: 27 ago. 2017.

OLIVEIRA, Antônio Eduardo Cerqueira de; BUZATTO, Cléber César. 2019: em contraponto ao retorno à era das trevas, a esperança na teimosia e resistência indígena. In: CONSELHO INDIGENISTA MISSIONÁRIO (CIMI). Relatório Violência contra os povos indígenas no Brasil - Dados de 2019. Brasília, DF: CIMI, 2020. p. 11-13.

PALOSCHI, Dom Roque. Povos indígenas do Brasil e a contínua angústia de ver suas vidas e terras ceifadas: Até quando? In: CONSELHO INDIGENISTA MISSIONÁRIO (CIMI). Relatório Violência contra os povos indígenas no Brasil - Dados de 2019. Brasília, DF: CIMI, 2020. p. 9-10.

PREZIA, Benedito. História da resistência indígena: 500 anos de luta. São Paulo: Expressão Popular, 2017.

RAMOS, Anatália Daiane de Oliveira; CABRAL, Cristiano Apolucena; AZEVEDO, Eva Emília Freire do Nascimento; CAETANO, Edson. Capitalismo, território e conflitos: a resistência dos povos e comunidades tradicionais no Brasil. Revista PerCursos, Florianópolis, v. 19, n. 40, p. 186 - 220, maio/ago. 2018. Disponível em: http://www.periodicos.udesc.br/index.php/percursos/article/view/198472461940201818 6/pdf. Acesso em: 23 nov. 2018. 
RANGEL, Lucia Helena; LIEBGOTT, Roberto Antônio. Bolsonaro estruturou um governo de depredadores e destruidores de vidas. CONSELHO INDIGENISTA MISSIONÁRIO (CIMI). Relatório Violência contra os povos indígenas no Brasil Dados de 2019. Brasília, DF: CIMI, 2020. p. 14-18.

RANGEL, Lucia Helena; LIEBGOTT, Roberto Antônio. Disputas pelo poder político no país causam aumento da violência contra os povos. In: CONSELHO INDIGENISTA MISSIONÁRIO (CIMI). Relatório Violência contra os povos indígenas no Brasil Dados de 2016. Brasília, DF: CIMI, 2017. p. 15-17.

RIBEIRO, Darcy. Os Índios e a civilização: a integração das populações indígenas no Brasil moderno. 3 ed. Petrópolis, RJ: Vozes, 1979.

ROQUETTE-PINTO, Edgar. Rondônia. 6 ed. São Paulo: Ed. Nacional; Brasília: INL, 1975.

SNETHLAGE, Emil-Heinrich. Vocabulário da língua Puruborá. Disponível em: http://etnolinguistica.wdfiles.com/local--files/emil\%3A4/borobura transcription.pdf. 1934a. Acesso em: 25 ago. 2017.

SNETHLAGE, Emil-Heinrich. Wörterverzeichnis der Boroburá. Disponível em: http://etnolinguistica.wdfiles.com/local--files/emil\%3A3/borobura.pdf. 1934b. Acesso em: 25 ago. 2017.

THOMPSON, Edward Palmer. Costumes em comum: estudos sobre a cultura popular tradicional. Tradução Rosaura Eichemberg. São Paulo: Companhia das Letras, 1998. 